\title{
Unreciprocated sedimentation along a mud-dominated continental margin, Gulf of Mexico, U.S.A.: Implications for sequence stratigraphy in muddy settings devoid of depositional sequences
}

\author{
Andrew. S. Madof ${ }^{1 *}$, Nicholas Christie-Blick ${ }^{2}$, Mark H. Anders ${ }^{3}$, and Lawrence A. Febo ${ }^{1}$ \\ ${ }^{1}$ Chevron Energy Technology Company, Houston, Texas 77002-7308, U.S.A. \\ ${ }^{2}$ Department of Earth and Environmental Sciences and Lamont-Doherty Earth \\ Observatory of Columbia University, Palisades, New York 10964-8000, U.S.A. \\ ${ }^{3}$ Department of Atmospheric, Oceanic, and Earth Sciences, George Mason University, \\ Fairfax, Virginia 22030, U.S.A. \\ *Corresponding author: andrew.madof@ chevron.com
}

\begin{abstract}
According to widely accepted sequence stratigraphic and fill-and-spill models, sedimentary cyclicity along continental margins is modulated by relative sea-level change, whereas smaller-scale intraslope accommodation is controlled by the filling of pre-existing bathymetric depressions. Although these concepts are presumed to apply to shelf-to-slope settings regardless of grain size, we have tested both hypotheses in the mud-prone lower Pliocene to Holocene of offshore Louisiana, Gulf of Mexico, and reach different conclusions. We determine that over the last 3.7 Myr, differential accumulation and accompanying salt tectonism dislocated the fine-grained shelf and slope, prevented the development of sedimentary reciprocity at 10-100 kyr time scales,
\end{abstract}


and inhibited fill-and-spill accumulation. We show that only $3 \%$ of "lowstand" mass transport deposits can be correlated to low stands in relative sea level, whereas approximately $30 \%$ of the deposits are related to transgressions and high stands; the remaining $67 \%$ are poorly constrained. Mass transport deposits also show no clear evidence of up-section increases in bypass. Based on our results, we conclude that the dominant control on stratigraphic architecture in offshore Louisiana was not relative sealevel change or patterns of accommodation, but rather differential deposition and concomitant salt-related subsidence, which controlled the distribution of facies, timing and location of mass transport deposits, and rates of sediment accumulation. Our conclusions highlight the importance of sediment supply and local tectonism, and caution against a priori use of conventional sequence stratigraphic and fill-and-spill models to decipher the stratigraphic evolution of actively-deforming mud-dominated continental margins. We therefore recommend treating stratigraphic models as testable hypotheses, rather than as methods of interpretation, particularly in fine-grained areas devoid of welldeveloped depositional sequences and in settings lacking intraslope ponded-to-perched accumulations.

\section{Keywords}

Gulf of Mexico; seismic stratigraphy; reciprocal sedimentation; fill-and-spill; mass transport complex; minibasin; deep-water

\section{Introduction}


It has long been assumed that sea-level change constitutes the primary control on sedimentary cyclicity at continental margins (Vail et al., 1977; Haq et al., 1987; Vail, 1987; Haq et al., 1988; Jervey, 1988; Posamentier et al., 1988; Posamentier and Vail, 1988; Weimer, 1990; Posamentier and Allen, 1999; Posamentier and Kolla, 2003; Saller et al., 2004; Catuneanu et al., 2011). According to this view, sediments accumulate preferentially on the shelf when sea level is high and in off-shelf locations when sea level is low - a pattern that has been referred to as reciprocal sedimentation (Wilson, 1967). The transitions between these different styles of deposition are thought to correspond with the rising and falling of base level (forced regression - see Posamentier et al., 1990). Variations in facies, stratigraphic architecture, and the development of depositional sequences therefore are interpreted to relate closely to sea-level change. Although relative changes in sea level are envisaged in terms of the interaction between eustasy and subsidence (Jervey, 1988), the concept does not provide a clear view of threedimensional effects or the impact of local patterns of deformation.

Intraslope sedimentation is thought to be influenced also by a second factor in settings associated with salt tectonics: the manner in which bathymetric depressions (minibasins) are filled and bypassed, punctuating the down-system transport of sediment (Prather et al., 1998; Beaubouef and Friedmann, 2000; Booth et al., 2000; Winker and Booth, 2000; Booth et al., 2003; Mallarino et al., 2006; Prather et al., 2012). In the socalled fill-and-spill model, depositional patterns are assumed to be controlled solely by ponded-to-perched sediment accumulation and not by varying rates of differential subsidence, which are presumed to be operating on significantly longer time scales. 
This study uses two-dimensional (2-D) and three-dimensional (3-D) seismic and biostratigraphic data from early Pliocene to Holocene deposits, offshore Louisiana (Gulf of Mexico), to test well-accepted reciprocal sedimentation and fill-and-spill models. We extend the conclusions of Madof et al. (2009) by incorporating additional 3-D seismic from the intraslope setting and regional 2-D seismic from the shelf, as well as biostratigraphic data. We find that through our integrated analysis, there exists no simple spatial or temporal relationship between the shelf and slope over the past $\sim 3.7 \mathrm{Myr}$. This conclusion is based on the interpretation that stratigraphic surfaces in offshore Louisiana are discontinuous across shelf-to-slope settings, that the mud-prone continental margin is generally devoid of well-developed depositional sequences, and that the study area was not largely influenced by persistent and large-scale coarse-grained sediment sources from the early Pliocene to Holocene.

Our study area, which includes portions of South Pelto, Ship Shoal, South Timbalier and Bay Marchand, Ship Shoal South Addition, South Timbalier South Addition, Ewing Bank, and Green Canyon protraction areas (Figures 1 and 2), has received significant academic and industrial attention owing to the abundance of hydrocarbons in shallow to deep-marine sands (Woock and Kin, 1987; McBride et al., 1998; Varnai, 1998; Weimer et al., 1998; Quinn, 2005; Quinn, 2006). Although much of the data acquired for oil and gas exploration in the Gulf of Mexico is proprietary and confidential, our study focuses on the commercially less sensitive stratigraphy above the allochthonous salt canopy. 


\section{Geological setting}

\subsection{Tectonics}

The study area includes portions of the inner and outer continental shelf and upper slope, offshore Louisiana (Figure 1), and is part of the larger Gulf of Mexico passive continental margin, which formed during the break-up of Pangea and development of the North American, South American, and African plates (Buffler and Sawyer, 1985;

Salvador, 1987; Feng et al., 1994; Pindell and Kennan, 2009). During the late Triassic to early-middle Jurassic, crustal extension was accommodated on basement-involved normal faults. Evaporation of sea water in restricted marine embayments immediately prior to continental separation resulted in the accumulation of $\sim 1-3 \mathrm{~km}$ of middle Jurassic Louann salt in two structurally-controlled depressions (Salvador, 1991; Bird et al., 2005). These depressions, which were separated by a mid-oceanic ridge, were stranded on the northern and southern margins as the Gulf of Mexico widened via seafloor spreading (see Figure 2 of Sandwell et al., 2014).

Cenozoic loading of evaporites in the northern Gulf of Mexico gave way to largescale and in-sequence salt-related structures: an inboard shelf detachment province and an outboard slope minibasin province. During the Oligocene to Miocene, the onset of extension above the detachment level corresponded with the development of largedisplacement listric normal faults that soled into a regional post-Paleogene interval. Lateral spreading continued into the Plio-Pleistocene, leading to numerous detachment structures on the outer shelf and to well-developed intraslope salt dome-minibasins on the slope (Diegel et al., 1995). It is these salt dome-minibasins, circular to elliptical 
subsidence-related depressions flanked by salt stocks, that are responsible for the current bathymetric configuration of the northern Gulf of Mexico (see Figure 1).

\subsection{Sedimentation}

Since the early Neogene, accommodation in the Gulf of Mexico was controlled primarily by deposition and contemporaneous subsidence into shallow salt displaced from depth (i.e., allochthonous). From the late Miocene to late Pliocene, the ancestral Mississippi River migrated westward (Winker and Booth, 2000), and delivered sediment to shelf and intraslope areas. Coarse-grained deep-water sediments are thought to have ponded in intraslope depressions, with the locus of sedimentation positioned on the upper continental slope (Prather et al., 1998). By the early to middle Pleistocene, the Mississippi River captured the Ohio and western Appalachian drainage basins, followed by the upper Missouri and Great Plains catchment areas. This drainage reorganization resulted in a significant increase in sediment supply, which along with the development of submarine canyons on the shelf (Prather et al., 1998; Galloway et al., 2000; Galloway et al., 2004; Galloway et al., 2011), led to bypassing of fine-grained sediments through upper slope minibasins and ultimately to their deposition on the lower slope. The locus of sedimentation thus shifted basinward with respect to time.

Over the last $120 \mathrm{kyr}$, areas outboard of major Quaternary sediment sources in the northern Gulf of Mexico (e.g., Rio Grande, Colorado, and Brazos drainages) are thought to have been significantly influenced by eustatic change (Kolla et al., 2000; Anderson et al., 2004; Anderson et al., 2016). As a result, highstand, lowstand, and transgressive 
deposits are found to track with oxygen isotope stage (see Anderson et al., 2004). Yet in areas lateral to sand-prone accumulations, and in successions older than the Quaternary (this study), the effect of sea-level change on the development of muddy successions has not been widely recognized.

\subsection{Study Area Salt Tectonics}

In the vicinity of the study area, the Louisiana shelf is underlain by a series of prominent seaward-dipping listric normal faults that sole into allochthonous salt (Diegel et al., 1995). Faulting for the most part pre-dates the early Pliocene, and is localized above salt stocks. These salt structures pass downdip beneath salt-controlled depressions, and under the Fuji and Mazama-Hornet minibasins, which are well developed on the upper continental slope. The basins, which are approximately $30 \mathrm{~km}$ (18.6 mi) in length and 5-17 km (3.1-10.6 mi) in width (Figure 2), formed during the late Pliocene to Holocene, as sediment loading caused the salt to rise diapirically from depth. As a result, sub-horizontal to vertical salt bodies currently surround basin depocenters, while growth faults related to salt withdrawal mark the northern flank of both Fuji and Hornet basins (McBride, 1997).

\section{Methodology}

\subsection{Seismic reflection data}

The 2-D and 3-D seismic reflection data used in this study cover approximately $11,212 \mathrm{~km}^{2}\left(4,329 \mathrm{mi}^{2}\right)$ of the Louisiana offshore (Figure 2A). The 2-D profiles intersect 
the 3-D volume (Fuji, Mazama, and Hornet basins; Figure 2B) at the continental slope, which is located in the southern part of the study area. At that location (Figure 3), check shot data from Soto (1997) for the Fuji \#1 well (GC 506 Texaco 1) were used to construct a time-to-depth plot (Figure 4A) and an interval sediment velocity curve (Figure 4B). Sediment velocities, which range from $1,524 \mathrm{~m} / \mathrm{s}(5,000 \mathrm{ft} / \mathrm{s})$ near the seafloor at a depth of $1,710 \mathrm{~ms}$ (two way travel time, TWTT; $1,301 \mathrm{~m} ; 4,268 \mathrm{ft}$ ) to $2,086 \mathrm{~m} / \mathrm{s}(6,844 \mathrm{ft} / \mathrm{s}$ ) at 6,509 ms TWTT $(6,789 \mathrm{~m} ; 22,275 \mathrm{ft})$, were used to estimate thickness for seismic stratigraphic intervals in the study area.

The 2-D data, acquired in 2002-2003 and processed in 2003, are distributed along 21 north-south profiles, and intersect 48 sections oriented east-west (Figure 2). The data represent a total line length of over 5,428 $\mathrm{km}(3,372.8 \mathrm{mi})$, and extend to $6,000 \mathrm{~ms}$ TWTT. North-south lines are from 5.6-160.7 km (3.5-99.9 mi) long, and are located 1-10 $\mathrm{km}(0.6-6.2 \mathrm{mi})$ apart with an average spacing of less than $3.5 \mathrm{~km}(2.2 \mathrm{mi})$. East-west trending sections are 2.6-62.7 km (1.6-39 mi) long, and are located 1.5-16.5 km (0.9-10.3 mi) apart, also with an average spacing of less than $3.5 \mathrm{~km}(2.2 \mathrm{mi})$.

The 3-D seismic volume, acquired in 1999-2000 and reprocessed in 2001, covers 78 outer continental shelf (OCS) blocks on the upper slope, encompasses a total surface area of more than $1,820 \mathrm{~km}^{2}\left(702.7 \mathrm{mi}^{2}\right)$, and extends to a depth of $6,000 \mathrm{~ms}$ TWTT $(6,050 \mathrm{~m} ; 19,848 \mathrm{ft}$; Figure 2). The volume has a $4 \mathrm{~ms}$ vertical sampling rate, and a bin spacing of $20 \times 12.5 \mathrm{~m}$ (65.6 x $41 \mathrm{ft})$. An 18 block sub-volume of this dataset provided the basis for our earlier article (Madof et al., 2009). 
Frequency, amplitude, and phase are comparable in the two seismic datasets (Figure 5), thereby easing the correlation of specific seismic features between 2-D lines (shelf) onto the 3-D volume (slope). Figure 5A and 5D displays the amplitude-frequency spectra of the data as a function of depth, and shows that on average, the 2-D data range from 9-20 Hz, whereas the 3-D data range from 10-40 Hz (dominant frequency) (see Table 1). The phase of the data, which was determined from the sea floor reflection (Figure 5B and 5E), is estimated as zero (American) in the 2-D data, and tends negatively in the 3-D data. Wavelength was calculated by dividing the interval sediment velocity (Figure 4B) by the dominant frequency (Figure 5A). The limit of separability (i.e., seismically resolving a top from a base - tuning or resolution) was calculated by taking one quarter of the wavelength. Deposits above tuning can be measured in cross section and observed in map view; deposits above the limit of detectability (i.e., one eighth of the wavelength) are too thin to be observed in cross section, but can be readily detected in plan view in 3-D data.

Wavelength, separability, and detectability are plotted as a function of depth in Figure 5C and 5F (see Table 1). Wavelengths from the 2-D data range from approximately $100 \mathrm{~m}$ (measured from $0-2,000 \mathrm{~ms}$ ) to $280 \mathrm{~m}$ (measured from 4,000-6,000 $\mathrm{ms}$ ), while wavelengths from the 3-D data range from $60 \mathrm{~m}$ (measured from 2,000-4,000 $\mathrm{ms}$ ) to $250 \mathrm{~m}$ (measured from 4,000-6,000 ms). Uncertainty in interpretations, as well as wavelength, therefore increases with depth. 


\subsection{Age control and biostratigraphy}

Available age control within the study area consists of 10 late Neogene to Quaternary biostratigraphic datums. These were used for regional correlation and for the creation of an internally consistent time-stratigraphic framework. Four shelf markers were established in wells drilled in the northern portion of the study area, and six slope datums in wells drilled in southern Fuji and Mazama basins. It proved not possible for us to gain access to proprietary borehole data collected beneath the shelf; for this reason, we are not able to identify the specific wells on which the biostratigraphic interpretation is based.

The shelf biostratigraphy is based on last occurrences of the early Pliocene planktonic coccolith Amaurolithus tricorniculatus ( 3.7-3.96 Ma; Poore et al., 1983; Berggren et al., 1985; Roof et al., 1991; Knappertsbusch, 2000); two late Pliocene planktonic foraminifers, Pulleniatina obliquiloculata ( 3.33-3.56 Ma; Shipboard Scientific Party, 1995; Chaisson and Pearson, 1997) and Globorotalia multicamerata ( 2.9-3.12 Ma; Berggren et al., 1985; Chaproniere et al., 1994; Berggren et al. 1995b; Ragaini et al., 2008); and the early Pleistocene benthic foraminifer Angulogerina B ( 1.52.3 Ma; Anderson et al., 1991; Zhang and Watkins, 1994; Galloway et al., 2000; Galloway, 2001). In an earlier unpublished investigation, these 4 shelf markers were tied to a regional and merged 2-D/3-D seismic survey, and used to create regional-scale biostratigraphic horizons for the northern Gulf of Mexico (M. Filewicz, personal communication, 2008). 
The slope biostratigraphy is based on last occurrences of the late Pliocene planktonic coccolith Discoaster brouweri ( 1.89-2.06 Ma; Backman and Pestiaux, 1987; Berggren et al., 1995a; Lourens et al., 1996; Lourens et al., 2004); two early Pleistocene benthic foraminifers, Hyalinea balthica ( 1.22 Ma; Waterman et al., 2009) and Stilostomella antillea ( 0.78 Ma; Witrock et al., 2003); two middle Pleistocene planktonic coccoliths Gephyrocapsa caribbeanica $(\sim 0.21-0.25 \mathrm{Ma}$; Hine and Weaver, 1998) and Pseudoemiliania lacunosa ( 0.45-0.46 Ma; Thierstein et al., 1977; Gard, 1988; Raffi and Flores, 1995; Flores and Marino, 2002); and one benthic foraminifer Globorotalia inflata ( 0.0105-0.012 Ma; Kennett et al., 1985). The 6 slope datums were established while drilling in southern Fuji and Mazama basins, and tied to 3-D seismic data at that time (T. Elliott, personal communication, 2006). Uncertainties in the position of these markers permit locations as much as $80 \mathrm{~ms}(72.2 \mathrm{~m} ; 236.9 \mathrm{ft})$ below and as much as $20-25 \mathrm{~ms}(18-22.6 \mathrm{~m} ; 59.2-74 \mathrm{ft})$ above currently interpreted levels.

\subsection{Reflection tracing}

Although conventional seismic stratigraphic methods hinge on tracing reflections to delineate unconformity-bounded units (Mitchum et al., 1977), sequences in our study area are not well developed, and reflections are physically discontinuous over distances greater than tens of kilometers (Figure 6A). As such, the use of biostratigraphic datums were necessary to establish a regional time-stratigraphic framework (Figure 6B), which extends from the northern limit of the inner shelf (2-D grid) to the northern portion of the upper slope (3-D volume). 
Biostratigraphic datums tied to 2-D data on the shelf were manually mapped southward towards the slope. At locations where faulting and localized salt stocks offset horizons, loops were tied around structural complexities to minimize miscorrelating across them. Some "jump correlations" were nonetheless unavoidable. With the exception of tracing Angulogerina $B(\geq 1.5 \mathrm{Ma}$ ) into Mazama basin, faulting and the occurrence of salt bodies hindered correlation of shelf datums southward of the northern limit of Fuji and Mazama basins. Accordingly, the overlying P. lacunosa ( $\geq 0.45 \mathrm{Ma})$ marker was the only slope datum that could be tied around structure from the 3-D volume to the 2-D seismic grid, and traced northward beneath the shelf. Smaller-scale stratigraphic features (i.e., reflection truncations, shingled and oblique reflections, and chaotic intervals) were subsequently mapped in detail between 2-D regional surfaces.

Eighty-eight surfaces were picked on the 3-D volume (i.e., 30 in Fuji basin; 22 in Mazama basin; 5 in Hornet basin; and 31 in between basins) primarily on the basis of continuity and amplitude, and were used to interpret seismic facies in the intraslope setting. High-amplitude laterally continuous surfaces were consequently chosen directly above or below chaotic intervals, and where reflections display a low cross-sectional continuity and ribbon-shaped plan-view morphology. As outlined by Madof et al. (2009), horizons were picked variously on a peak, trough, or zero crossing. The 3-D propagator algorithm was subsequently used to cross-correlate nearest-neighbor seismic traces to within a defined interval of confidence. This procedure resulted in 3-D seismic surfaces, which were inspected on every inline and crossline, and manually corrected where the propagator algorithm miscorrelated. 
In addition to scrolling through the data and picking reflections, seismic facies were interpreted on 3-D data via horizon slicing and time slicing (see Brown et al., 1981; Zeng et al., 1995; Zeng and Hentz, 2004). Horizon slicing, a procedure that requires mapping a reflection, shifting it in time, and extracting amplitude onto the surface, was most useful when the interval of interest displayed irregular topography. Time slicing, a method that involves moving a horizontal plane parallel to the time axis, was used on flattened volumes to identify stratigraphic elements, and quickly to place groups of reflections into an orientation consistent with deposition onto a flat surface. These widely-used seismic interpretation techniques established confidence in recognizing and delineating seismic facies in three dimensions (see Posamentier et al., 2014).

\section{Seismic facies, large-scale incision, and stratigraphic architecture}

Amplitude, continuity, internal architecture, external form, lower and upper bounding surfaces, and truncation were used to identify five seismic facies, and to delineate large-scale incision. Seismic facies consist of hemipelagites and muddy turbidites, followed in descending order of abundance by mass transport complexes (MTCs), shelf edge sediments, and channelized sandy turbidites (Figures 7 and 8). Hemipelagites and muddy turbidites are positioned throughout all stratigraphic intervals within the study area, whereas MTCs become more prevalent in outboard areas and in younger sections above the Angulogerina $B(\geq 1.5 \mathrm{Ma})$ and $H$. balthica $(\geq 1.22 \mathrm{Ma})$

datums. In proximal regions, five complexes of shelf edge sediments directly overlie and underlie the $P$. lacunosa ( $\geq 0.45 \mathrm{Ma}$ ) datum; these deposits consist of offlapping oblique 
to shingled clinoforms and cannot be traced updip or downdip into unconformitybounded sequences. In distal locations, channelized sandy turbidites are contained within slope valleys above the $P$. lacunosa $(\geq 0.45 \mathrm{Ma})$ datum, and cannot be mapped outside of Fuji and Mazama basins. Large-scale inboard incision, on the other hand, is manifested as six shelfal submarine canyons that are positioned directly above and below the $P$.

lacunosa $(\geq 0.45 \mathrm{Ma})$ datum. These features are not mappable over distances greater than tens of kilometers because they are either truncated by a high-angle erosional surface or extend off the 2-D grid.

Analogous seismic facies have been identified and well documented throughout the Gulf of Mexico (Prather et al., 1998; Beaubouef and Friedmann, 2000; Booth et al., 2000; Booth et al., 2003; Posamentier, 2003; Expedition 308 Scientists, 2005; Mallarino et al., 2006; Kolla et al., 2007; Prather et al., 2012), as well as in a variety of structural and stratigraphic settings worldwide (Deptuck et al., 2003; Haflidason et al., 2004; Lee et al., 2004; Haflidason et al., 2005; Martinez et al., 2005; Moscardelli et al., 2006; Deptuck et al., 2007; Moscardelli and Wood, 2008).

\subsubsection{Hemipelagites and Muddy Turbidites: Observations}

The hemipelagite and muddy turbidite facies consists of laterally continuous, parallel, nondescript high- to low-amplitude reflections. The facies exhibits a tabular, wedge, or lenticular external form, and is underlain by a non-erosive, planar or hummocky basal surface. Successions are distributed throughout the study area, 
becoming less prevalent at shallow stratigraphic levels and at southern (intraslope) locations.

Units constituting the facies range in thickness from $\leq 10 \mathrm{~ms}(9 \mathrm{~m} ; 29.6 \mathrm{ft})$ to $\geq$ $1,000 \mathrm{~ms}(902.5 \mathrm{~m} ; 2,960.9 \mathrm{ft})$, and in surface area from $\leq 250 \mathrm{~m}^{2}\left(2,691 \mathrm{ft}^{2}\right)$ to $\geq 250$ $\mathrm{km}^{2}\left(96.5 \mathrm{mi}^{2}\right)$. Individual deposits generally thin and thicken above topographic highs and lows, respectively. The facies is therefore not well developed over minibasinflanking salt stocks, but is abundantly present in basin depocenters (see Figures 9-10).

\subsubsection{Hemipelagites and Muddy Turbidites: Interpretations}

We interpret the hemipelagite and muddy turbidite facies to represent a mixture of both gravity- and suspension-driven sedimentation. Gravity-driven accumulations result from non-erosive mud-rich turbidity currents derived from fine-grained sediments located in inboard regions, whereas suspension-driven deposits (drapes) are a consequence of hemipelagic fallout and condensation during times of decreased sediment supply. The resolution of available seismic data does not allow partitioning hemipelagites from muddy turbidites.

\subsubsection{MTCs: Observations}

The MTC facies consists of laterally continuous to discontinuous, hummocky to chaotic high- to low-amplitude reflections. Accumulations in the study area are locally disorganized, folded, and faulted. The facies exhibits a tabular, wedge, lenticular, or mounded external form, and is underlain by erosional, scoured, or non-erosive high- to 
low-angle surfaces. Successions are located throughout the offshore Louisiana area, becoming more abundant and amalgamated in progressively shallower stratigraphic intervals and at southern (intraslope) locations. Within the 3-D volume, at least twelve MTCs are identified in Fuji basin (Figure 9), and with no fewer than twenty such deposits in Mazama basin (Figure 10).

Units constituting the facies range in thickness from $\leq 10 \mathrm{~ms}(9 \mathrm{~m} ; 29.6 \mathrm{ft})$ to $\geq$ $700 \mathrm{~ms}(631.8 \mathrm{~m} ; 2,072.7 \mathrm{ft})$, in surface area from $\leq 35 \mathrm{~km}^{2}\left(13.5 \mathrm{mi}^{2}\right)$ to $\geq 537 \mathrm{~km}^{2}$ $\left(207.3 \mathrm{mi}^{2}\right)$, and in volume from $\leq 1 \mathrm{~km}^{3}\left(0.2 \mathrm{mi}^{3}\right)$ to $\geq 139 \mathrm{~km}^{3}\left(33.3 \mathrm{mi}^{3}\right)$. Successions within the facies generally thin towards topographic highs.

The internal architecture of the MTC facies is variably disorganized, folded, and faulted. Disorganization ranges from slightly inclined reflections to nearly complete seismic transparency. Where reflections are folded (Figure 11), fold wavelengths range from $\leq 100 \mathrm{~m}(328 \mathrm{ft})$ to $\geq 1.5 \mathrm{~km}(0.9 \mathrm{mi})$, and amplitudes from $\leq 20 \mathrm{~ms}(18 \mathrm{~m} ; 59.2 \mathrm{ft})$ to $\geq 100 \mathrm{~ms}(90.2 \mathrm{~m} ; 296 \mathrm{ft})$. Where reflections are offset, faulting is generally found to be of reverse separation. In one example from Fuji basin, 0.8-1.3 km (0.5-0.8 mi) of shortening (calculated from fault heave - MTC no. 9F) was accommodated on numerous reverse faults located within the deposit (see Madof et al., 2009).

Basal features flooring the MTC facies consist of erosional, scoured, and nonerosive high- to low-angle surfaces. Erosion is thought to have removed $\leq 250 \mathrm{~m}^{2}(2,691$ $\left.\mathrm{ft}^{2}\right)$ to $\geq 50 \mathrm{~km}^{2}\left(19.3 \mathrm{mi}^{2}\right)$ of material, resulting in $\leq 10 \mathrm{~ms}(9 \mathrm{~m} ; 29.6 \mathrm{ft})$ to $\geq 200 \mathrm{~ms}$ $(180.5 \mathrm{~m} ; 592.2 \mathrm{ft})$ of relief. Erosion is generally greatest at areas flanking topographic highs. Linear scours (Figure 12) range in length from $\leq 12.5 \mathrm{~m}(41 \mathrm{ft})$ to $\geq 32.5 \mathrm{~km}(20.2$ 
mi), in width from $\leq 12.5 \mathrm{~m}(41 \mathrm{ft})$ to $\geq 2.5 \mathrm{~km}(1.6 \mathrm{mi})$, and in relief from $\leq 10 \mathrm{~ms}$ ( $9 \mathrm{~m}$; $29.6 \mathrm{ft})$ to $\geq 50 \mathrm{~ms}(45.1 \mathrm{~m} ; 148 \mathrm{ft})$. Converging and diverging scours are found to terminate abruptly down system. Where erosional features do not floor MTCs, deposits are underlain by non-erosive high- to low-angle surfaces.

\subsubsection{MTCs: Interpretations}

We interpret the MTC facies to represent a spectrum of gravity-driven sedimentation, resulting from erosive and non-erosive slides, slumps, and debris flows (Madof et al., 2009). These subdivisions are below the resolution of available seismic data, but are possible to distinguish at the scale of outcrop, and piston and conventional core (cf., Mulder and Cochonat, 1996; McHugh et al., 2002; Pickering and Corregidor, 2005; Jenner et al., 2007; Tripsanas et al., 2008; Ogata et al., 2014). The lithology of the MTC facies is a function of the original failure material, as well as sediment entrained during flow, which we interpret to consist primarily of hemipelagites and muddy turbidites.

In the study area, the internal architecture and basal features associated with MTCs form as a result of downslope motion. As the materials flow, trailing edges are thinned, extended, and faulted (listric, normal structures; Edwards et al., 1995). Although updip regions may be bounded by headscarps and characterized by tilted blocks, zones of evacuation are rarely observed on our seismic data. Yet, at the leading edges of accumulations, thickening, disorganization, folding, and faulting (high-angle reverse and thrust structures) result in zones of accumulation that are readily observed in the region. 
These features are generally bounded by frontal ramps and are characterized by compressional ridges (Martinez et al., 2005; Moscardelli et al., 2006; see Figure 5D and 6 of Madof et al., 2009 for examples). Although updip and downdip zones have been found to be linked by detached transfer faults, these features frequently have poor preservation potential and are not observed in our seismic data.

Basal features flooring MTCs develop as a result of both coupling to the substrate and decoupling from it, processes that are manifested in the study area as incision and low-angle detachment surfaces, respectively. Where erosion has occurred, the depth of incision is generally found to be greatest under the thickest portion of the deposit (see Madof et al., 2009). In our area, the development of linear scours arises as portions of pre-existing material (cohesive blocks) are integrated into the deposit, and subsequently erode into the underlying substrate. Scours are topographically sensitive, and are observed to converge in confined settings and diverge in unconfined ones; these features terminate down system as blocks disassemble or are forced into the overlying deposit at breaks in slope (Posamentier and Kolla, 2003). Where high- to low-angle detachment surfaces underlie MTCs in our study area, hydroplaning (i.e., sliding on a basal fluidized layer) is assumed to be the dominant transport mechanism (Mohrig et al., 1998; Gee et al., 2006).

\subsubsection{Shelf Edge Sediments: Observations}

The shelf edge facies consists of five complexes of laterally continuous, oblique to shingled high- to low-amplitude offlapping reflections. The facies exhibits a wedge to 
lenticular external form, and is underlain by non-erosive planar to concave, high- to lowangle surfaces. The five units are present north of the modern shelf-slope break and extend beyond the 2-D data (Figure 13)

Units constituting the facies range in thickness from $\leq 140 \mathrm{~ms}(126.3 \mathrm{~m} ; 414.5 \mathrm{ft})$ to $\geq 330 \mathrm{~ms}$ ( $297.8 \mathrm{~m} ; 977.1 \mathrm{ft}$ ), in length (measured parallel to the apparent dip of reflections) from $\leq 2.5 \mathrm{~km}(1.6 \mathrm{mi})$ to $\geq 49.5 \mathrm{~km}(30.8 \mathrm{mi})$, and in width (measured perpendicular to the apparent dip of reflections) from $\leq 2 \mathrm{~km}(1.2 \mathrm{mi})$ to $\geq 58.5 \mathrm{~km}(36.4$ $\mathrm{mi})$.

\subsubsection{Shelf Edge Sediments: Interpretations}

We interpret the shelf edge facies to represent progradation of sand-prone shallow marine sediments (clinothems) into progressively deeper water. These deposits may be part of a larger shelf-edge deltaic or shoreface system, but in the absence of lithofacies calibration, it is not currently possible to further refine our interpretation. Where observed, we interpret offlapping clinoforms to signify the development of bypass with steep clinoform gradients suggesting relatively high-energy depositional environments (Mitchum et al., 1977; Tesson et al., 2000; Patruno et al., 2015). Asymmetric clinoform lengths, seen on Figure 13, are interpreted to be controlled by complex threedimensional shifts in the relationship between accommodation creation and sediment supply (see Madof et al., 2016), and therefore imply composite along-strike geometries.

\subsubsection{Channelized Sandy Turbidites: Observations}


The channelized sandy turbidite facies consists of laterally discontinuous, variably arranged high-amplitude reflections (see Figures 9 and 10 of Madof et al., 2009). Accumulations in the study area display a ribbon-shaped external form and low crosssectional continuity. The facies exhibits tabular, wedge, lenticular, and mounded internal elements, and is underlain by erosional and scoured high- to low-angle surfaces. Within the 3-D volume, at least three sets of channelized sandy turbidites are identified in Fuji basin, and at least one in Mazama basin (Figure 14).

Units constituting the facies range from individual channels to sets of channel complexes. Individual channels are approximately $\leq 10 \mathrm{~ms} \mathrm{(7.9} \mathrm{m;29.6} \mathrm{ft)} \mathrm{in} \mathrm{depth,} \mathrm{with}$ sets of channels displaying $\geq 40 \mathrm{~ms}$ ( $36.1 \mathrm{~m} ; 118.4 \mathrm{ft})$ of relief. Deposits range in width

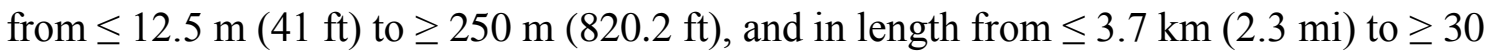
km (18.6 mi). Elements are variably arranged into channel complexes, each bounded below by a major scour surface (i.e., reflection truncation) and above by a planar to irregular boundary. Complexes are $\leq 75 \mathrm{~ms}(67.7 \mathrm{~m} ; 222.1 \mathrm{ft})$ to $\geq 200 \mathrm{~ms}(180.5 \mathrm{~m}$; $592.2 \mathrm{ft})$ deep, $\leq 0.7 \mathrm{~km}(0.4 \mathrm{mi})$ to $\geq 3 \mathrm{~km}(1.9 \mathrm{mi})$ wide, and $\geq 30 \mathrm{~km}(18.6 \mathrm{mi})$ long (see Madof et al., 2009).

Both small-scale channels and large-scale complexes display a meandering morphology and a bypass character. Where present, accumulations in the 3-D data generally show an up-section increase in sinuosity, length, and swing (meander-loop expansion), but lack sweep (down-system meander-loop migration). Levees and lateral accretion are not found to be associated with individual channels, and may be below seismic detectability. 


\subsubsection{Channelized Sandy Turbidites: Interpretations}

We interpret the channelized sandy turbidite facies to represent deposition from confined gravity-driven coarse-grained turbidity currents. Our interpretation of lithology is based on high-amplitude reflections and a ribbon-shaped external form, as well as from our calibration of seismic to well log and core (see Figure 3).

The morphology, bounding surfaces, and internal architecture associated with channelized sandy turbidites in our 3-D data result from the alternation of incision and deposition at a variety of scales (Deptuck et al., 2003; Deptuck et al., 2007; McHargue et al., 2011). We interpret composite and master scour surfaces located at the base of channel complexes to form during times of erosion; these features are subsequently filled and onlapped by channelized sandy turbidites, hemipelagites, and muddy turbidites during non-erosional episodes. Although incision associated with the base of individual channels develops as sediments flow downslope, this scale of erosion is well below the resolution of our seismic data. The lack of levees associated with the features also indicates either that channels in our study area were deeper than the thickness of a typical turbidity current, or that the upper parts of flows contained insufficient mud to account for significant deposition (Posamentier and Kolla, 2003).

We interpret changes in grain size, flow parameters, and gradient to be responsible for the up-section increase in sinuosity, length, and swing observed on our 3D seismic data (Peakall et al., 2000a; Kolla et al., 2007). These vertical changes develop through time as sandy turbidite channels broaden, are filled, and eventually bypassed 
(Peakall et al., 2000a, 2000b). Along with this evolution, deep-water channels in the 3-D data are observed to decrease in width and depth down system.

\subsubsection{Submarine Canyons: Observations}

Submarine canyons in the study area consist of either a composite or master basal scour surface, marked by reflection truncation, onlapped by high- to low-amplitude reflections of shingled, oblique, draping, and chaotic character. Incision ranges in depth from $\leq 10 \mathrm{~ms}(9 \mathrm{~m} ; 29.6 \mathrm{ft})$ to $\geq 815 \mathrm{~ms}(735.5 \mathrm{~m} ; 2413.1 \mathrm{ft})$, in width from $\leq 6.5 \mathrm{~km}(4$ mi) to $\geq 20 \mathrm{~km}(12.4 \mathrm{mi})$, and in length from $\leq 7.5 \mathrm{~km}(4.7 \mathrm{mi})$ to $\geq 52.5 \mathrm{~km}(32.6 \mathrm{mi})$. At least six submarine canyons are identified in the 2-D data, north of the modern shelfslope break (Figure 15), with the four oldest systems truncated by a high-angle northeastsouthwest oriented erosional surface. Canyons become progressively shallower, and generally wider, in an eastward direction.

\subsubsection{Submarine Canyons: Interpretations}

We interpret the submarine canyons to represent a complex process of multi-scale bypass and erosion (Harris and Whiteway, 2011), propagating downdip by incision (Imran et al., 1998) or updip by retrogressive failure (Pratson et al., 1994; Pratson and Coakley, 1996). Canyons are found to initiate as locally oversteepened sediments trigger eroding sediments to flow down slope, leading to the development of MTCs. Over time, incision propagates upslope, evolving into headward-eroding systems. Although both updip- and downdip-propagating mechanisms have been inferred for the generation of 
submarine canyons, it remains unclear if features in our study area may also have formed via submarine erosion by dense shelfal waters (Canals et al., 2006). In either case, submarine canyons on the 2-D data are filled and onlapped by a variety of deposits, such as shelf edge sediments, hemipelagites and muddy turbidites, and MTCs.

\subsection{Sediment transport directions}

We interpret shelf edge sediments (Table 2), submarine canyons (Table 3), and channelized sandy turbidites to have flowed south and southeast, whereas MTCs are thought to have had significantly more directional variability. Ten intrabasinal and two extrabasinal MTCs within Fuji basin were transported radially into the basin's depocenter (Madof et al., 2009), while eight intrabasinal and twelve extrabasinal deposits within Mazama basin were emplaced both radially and southwards, towards that basin's depocenter (Figures 16-17; Table 4). We find all MTCs within Fuji and Mazama (a total of 18 intrabasinal and 14 extrabasinal) to be contained within basin depocenters, and not to have breached the southern sill and flowed southwards.

The majority of MTCs that fill Fuji basin were sourced from its margins, while those that fill Mazama basin were derived from updip salt-controlled structural highs, which are currently located outboard of the modern shelf-slope break (Figure 18). Figure 19 shows the intrabasinal (squares) and extrabasinal (circles) MTCs filling Fuji and Mazama as a function of volume, and with respect to time. Based on available age control, a marked increase in MTC generation occurs at $\sim 0.45 \mathrm{Ma}$ in both basins, and continues to the present. Measurements also illustrate that smaller MTCs are far more 
prevalent than larger ones, with the most common volume being $10-20 \mathrm{~km}^{3}$ in Fuji basin and $0-10 \mathrm{~km}^{3}$ in Mazama basin (Figure 19C and 19D).

We estimate emplacement directions for MTCs from axial surfaces, basal erosion, head scarps, scours, and thinning directions. MTCs flowed approximately perpendicular to fold axial surfaces and head scarps, and parallel to underlying scours. Basal erosion and thinning directions were used to distinguish the center of the deposit from lateral and downdip margins (feather edges), and therefore provide less confidence in inferring sediment transport directions. Features located on basal surfaces of MTCs within Mazama basin were measured (Table 5) and plotted on rose diagrams (Figure 20).

\subsection{Stratigraphic architecture}

The stratigraphic architecture of the offshore Louisiana consists of two large-scale assemblages, bracketed by biostratigraphic intervals, and interpreted on the basis of facies types. The first assemblage spans from $\sim 3.7 \mathrm{Ma}$ to $\sim 0.45 \mathrm{Ma}$, and consists primarily of hemipelagites, muddy turbidites, and MTCs (see Figures 7-8); MTCs become more prevalent in increasingly shallower and outboard sections. The first assemblage is generally devoid of sand-prone systems in the offshore Louisiana.

The second assemblage spans from $\sim 0.45$ to $0.0 \mathrm{Ma}$, and in addition to the facies of the first assemblage, contains inboard sand-prone submarine canyon fill and shelf edge sediments, as well as outboard channelized sandy turbidites. The base of the second assemblage ( $\sim 0.45 \mathrm{Ma})$ is the only biostratigraphic datum that displays a potential for sequence stratigraphic significance: it has characteristics of an updip flooding surface 
(e.g., located above inner and outer shelf sand-prone systems - Figures 13 and 15) that grades laterally into an outboard sequence boundary (e.g., located below MTC no. 10F see Figure 9).

\section{Stratigraphic models}

\subsection{Sequence stratigraphy versus active deformation}

It is generally accepted that relative sea-level change results in reciprocal sedimentation at continental margins (Vail et al., 1977; Haq et al., 1987; Vail, 1987; Haq et al., 1988; Jervey, 1988; Posamentier et al., 1988; Posamentier and Vail, 1988; Weimer, 1990; Posamentier and Allen, 1999; Catuneanu, 2002; Posamentier and Kolla, 2003; Saller et al., 2004; Catuneanu, 2006; Catuneanu et al., 2011). According to this view, during high stands, sand is thought to accumulate preferentially in shallow-marine settings on the shelf, while hemipelagics accumulate in deep-water environments on the slope. As sea level falls, basinward-directed MTCs are initiated from upper slope failures triggered by increases in pore-fluid pressures in low permeability zones. During low stands, coarse-grained sediments bypass the shelf through incised valleys (sequence boundaries) that extend to the outer shelf and upper slope. Downdip of these erosional features, sand-rich deep-water systems are expected to overlie correlative conformities and to accumulate on the basin floor. At rises in sea level, water and sediment loading may engender slope destabilization, resulting in the generation of MTCs. However, the mechanics of this process remain unclear. Coarse-grained deposits are expected 
subsequently to fill incised valley systems on the shelf, as fine-grained sediments collect on the slope. Accumulations backstep and the cycle resets with a high stand of sea level. A fundamental assumption of models involving reciprocal sedimentation is that depositional sequences develop in close proximity to relatively long-lived and coarsegrained sediment sources. Yet, in lateral areas dominated by muddy accumulations (this study), sequences are rarely developed, making a test of stratigraphic concepts problematic. To correct for these issues, we examine the concept of reciprocal sedimentation by using our time-stratigraphic framework to compare patterns of observed facies (Figures 7-15) with those predicted by sequence stratigraphic models. We use the definition of relative sea level from Jervey (1988) to determine the relationship between eustasy and subsidence; the eustatic component of relative sea level (from Miller et al., 2005) is shown in Figure 21.To better understand the deformational component, we use geometric criteria from seismic data to determine uplift (upward-rotation of reflections) and subsidence (downward-rotation of reflections). The absolute value of vertical displacement is not possible to determine in the absence of high-resolution paleodepth proxies.

Based on our test, and the fact that the Louisiana margin is devoid of welldeveloped depositional sequences, we conclude that reciprocal sedimentation does not adequately describe the stratigraphic evolution of the continental margin during the late Pliocene to Holocene. Our determination is centered on the observation that cycles of sea-level change are not timed to seismic facies, reflection geometries, or significant surfaces. For example, MTCs in shelf-to-slope settings do not coincide with relative sea- 
level falls, and generally do not propagate away from the shelf-slope break. Out of the 32 total MTCs in Fuji and Mazama-Hornet basins (18 intrabasinal and 14 extrabasinal), only $3 \%$ (1 of $32-$ no. 9F) can be correlated to a low stand in sea level, approximately $30 \%$ (9 of $32-\operatorname{nos} .8 \mathrm{~F}-1 \mathrm{~F} ; 5 \mathrm{M})$ are correlatable to transgressions and high stands, and the remaining $67 \%$ (22 of 32) do not have sufficient age resolution to make a determination. In addition to the timing of MTCs, erosional surfaces located at the base of the deposits are not sequence boundaries because they are limited in areal extent, tied to specific salt structures, and do not extend onto the shelf. This is readily obvious from the base of the second assemblage ( $\sim 0.45 \mathrm{Ma})$, which laterally transitions from a flooding surface on the shelf into a localized sequence boundary on the slope.

In shelfal locations, clinoforms (Figure 13) are only observed in the study area during the last $\sim 0.45 \mathrm{Myr}$, and do not occupy the maximum basinward position at the largest sea-level fall ( 0.45 Ma). This implies that even if shallow marine deposits were influenced by sea-level change, they were not fundamentally controlled in the same way as Quaternary deposits (see Anderson et al., 2004; and Anderson et al., 2016). Submarine canyons (Figure 15), on the other hand, are present only before $\sim 0.45 \mathrm{Ma}$, and are not associated with major sand delivery to the study area (Figure 9). Nor are they tied to the largest sea-level fall. Based these observations, reciprocal sedimentation does not adequately describe the shelf or slope stratigraphy of offshore Louisiana because it makes incorrect assumptions on the origin of depositional cyclicity.

\subsection{Fill-and-spill versus subsidence and margin failure}


Fill-and-spill models have been used to interpret the stratigraphic evolution of the salt-controlled Gulf of Mexico slope (Satterfield and Behrens, 1990; Prather et al., 1998; Winker and Booth, 2000; Prather et al. 2012), and have been a significant exploration concept in the search for oil and gas in deep-water and mobile-substrate environments. According to these models, minibasins undergo a three-part evolution from ponded, to perched, to complete bypass (Beaubouef and Friedmann, 2000; Booth et al., 2000; Booth et al., 2003; Mallarino et al., 2006). The fill-and-spill cycle initiates as extrabasinal coarse-grained and slumped sediments are transported longitudinally into salt-bounded depressions. Along with hemipelagites, accumulations pond and heal minibasins to their spill points (Figure 22A - left). Continued fine-grained sediment perches from above the basin exit point to the local slope profile of the basin (Figure 22A - middle); erosion of pre-existing deposits subsequently initiates down-slope bypass (Figure 22A - right). Prather et al. (1998) applied fill-and-spill models to the Gulf of Mexico (their Figure 25), and concluded that $\sim 1 \mathrm{Myr}$ (2.85-1.84 Ma) of ponding (filling) gave way to more than $\sim 0.3 \mathrm{Myr}$ (1.05-0.70 Ma) of bypass (spilling) on the upper slope, and in Fuji and Mazama-Hornet basins more specifically. The authors determined that the transition from ponding to bypass was a consequence of increased rates of sediment accumulation, which resulted from the capture of the Ohio and Missouri Rivers by the Mississippi River.

We have tested the interpretations of Prather et al. (1998) on Fuji and MazamaHornet basins, and reach different conclusions. Based on our observations, we determine that during the last $3.7 \mathrm{Myr}$, ponding in basin depocenters was the dominant mode of sediment accumulation, and that no bypass or major down-system transport occurred. As 
a result, we propose a structural-stratigraphic model that better accounts for the seismic geometry and stratigraphic evolution of minibasins. Our model shows that displacement of salt with depth and in lateral areas leads to ponding of intrabasinal sediments (Figure 22B - left), which prompts depocenter subsidence and concomitant flank uplift (Figure 22B- middle). This dynamic and three-dimensional process leads to oversteepened and rotated basin margins, which subsequently fail and generate intrabasinal MTCs (Figure 22B - right). The process also occurs on a larger-scale and is responsible for creating extrabasinal MTCs. Because MTCs remobilize deposits on basin highs, hemipelagites and muddy turbidites occur only in thin carapaces above mini-basin flanks. Alternatively, where thick sediment accumulations exist over basin flanks, they tend to suppress surface expressions of underlying salt, and result in non-oversteepened conditions. This relationship implies a negative correlation between depth to salt and oversteepening (Figure 23). Regardless of the local effects of gradient-induced failure, our processdriven model casts doubt on the abundant use of fill-and-spill models on salt-controlled minibasins, and highlights the need for understanding active deformation during deposition, and especially in three dimensions (see Sylvester et al., 2015).

\section{Stratigraphic evolution of a decoupled shelf and slope}

Our study area represents a fine-grained and structurally-active end-member where salt tectonics are interpreted to have decoupled the shelf and slope from early Pliocene to Holocene times. Depositional processes occurring on the slope (i.e., MTCs), therefore, do not have shelfal equivalents, and vice versa. From the early Pliocene to 
middle Pleistocene, relatively slow sedimentation resulted in basinward-thinning shelf sediments (Figures 7-8), and decreased slope accumulation (Figure 24A). Diminished rates of deposition led to reduced subsidence, and as a result, halokinetic cycles episodically generated small numbers of MTCs (Figure 24B). In the northern part of the study area, because of kilometer-scale spacing of 2-D seismic profiles, individual MTCs cannot be tied to specific structures, but are assumed to have originated in a similar fashion. The lack of observed clinoforms (not including those in Figure 13) hinders an interpretation for the position and trajectory of the shelf-slope break, and may imply either that not enough coarse-grained sediment was available to develop these features, or that clinoforms were subsequently re-mobilized into MTCs. The paucity of submarine canyons also suggests that erosion was not a dominant process during this time. Early Pliocene to middle Pleistocene accumulations are thus interpreted to have recorded episodic halokinetic cycles on the shelf and slope, and not sea-level change or perchedto-ponded accommodation.

From the middle Pleistocene to present, comparatively rapid accumulation resulted in the deposition of basinward-thickening shelf deposits (Figures 7-8), and increased slope accumulation. Enhanced rates of sedimentation, along with a major sealevel low stand may have been responsible for the development of submarine canyons (Figure 24C) and shelf edge clinoforms (Figure 24D), which subsequently backstepped before $\sim 0.45 \mathrm{Ma}$ (Figure 24E). From this time until recent, increased loading-induced subsidence generated salt-controlled cycles, which were responsible for the vast number of MTCs found within the study area (Figure 24F). Middle Pleistocene to recent 
sedimentation is therefore inferred to have preserved an exceedingly incomplete record of eustatic oscillation on the shelf, and cyclicity controlled by salt tectonics on the slope. During the past $\sim 3.7 \mathrm{Myr}$, the absence of direct communication between shelf and slope areas led to a decoupling of these bathymetric provinces.

\section{Conclusions}

We have a taken an integrative approach to interpreting the stratigraphy of offshore Louisiana, by incorporating 2-D and 3-D seismic and biostratigraphic data. We have tested models relating to both reciprocal sedimentation and fill-and-spill processes, and instead determine that varying rates of differential sediment accumulation and subsidence into allochthonous salt better explain the stratigraphic evolution of the late Neogene to Quaternary. Sea-level change at 10-100 kyr cycles plays a minimal role in the development of facies distribution, stratigraphic architecture, and large-scale geometry. Our data suggest that fine-grained sedimentary systems with mobile substrates be reevaluated in terms of active deformation via differential subsidence, rather than a priori use of conventional sequence stratigraphic and fill-and-spill models. 


\section{Acknowledgements}

The authors acknowledge Chevron for summer internships (Madof) and for access to proprietary biostratigraphic data, Compagnie Générale de Géophysique-Veritas for the loan of 3-D seismic reflection data, TGS-NOPEC Geophysical Company for loan of 2-D seismic reflection data, Paradigm for providing access to commercial interpretation software, and National Science Foundation grant OCE 01-19019 for the support of related sequence stratigraphic studies (Christie-Blick). We are especially grateful to Tom L. Elliott, Mark Filewicz, Barney Issen, David C. Lentrichia, Ivan D. Marroquin, Martin A. Perlmutter, Serge Sauvagnac, Luc Schlumberger, Nat G. Smith, and Roger Witmer for making it possible to undertake this project. We thank Sean D. Connell, Ashley D. Harris, Simon Lang, and Morgan D. Sullivan for engaging discussions about earlier interpretations, as well as comments from Sverre Henriksen and two anonymous reviewers. Lamont-Doherty Earth Observatory contribution number 8065. 


\section{References}

Anderson, R. N., W. He, M. A. Hobart, C. R. Wilkinson, and H. R. Nelson, 1991, Active fluid flow in the Eugene Island area, offshore Louisiana: The Leading Edge, $v$. 10, p. 12-17.

Anderson, J. B., A. Rodriguez, K. C. Abdulah, R. H. Fillon, L. A. Banfield, H. A. McKeown, and J. S. Wellner, 2004, Late Quaternary stratigraphic evolution of the northern Gulf of Mexico margin: a synthesis, in J. B. Anderson, R. H. Fillon, eds., Late Quaternary stratigraphic evolution of the northern Gulf of Mexico margin: Society of Economic Paleontologists and Mineralogists Special Publication 79, p. $1-23$.

Anderson, J. B., D. J. Wallace, A. R. Simms, A. B. Rodriguez, R. W. R. Weight, and Z. P. Taha, 2016, Recycling sediments between source and sink during a eustatic cycle: Systems of late Quaternary northwestern Gulf of Mexico basin: Earth Science Review 153, p. 111-138.

Backman, J. and P. Pestiaux, 1987, Pliocene Discoaster abundance variations, deep sea drilling project site 606: biochronology and paleoenvironmental implications, in W. F. Ruddiman, R. B. Kidd, E. Thomas, et al., eds., Initial Reports, Deep Sea Drilling Project, 94: Washington (U. S. Government Printing Office), p. 903-910.

Beaubouef, R. T., and S. J. Friedmann, 2000, High resolution seismic/sequence stratigraphic framework for the evolution of Pleistocene intra slope basins, western Gulf of Mexico: depositional models and reservoir analogs, in P. Weimer, R. M. Slatt, J. Coleman, N. C. Rosen, H. Nelson, A. H. Bouma, M. J. Styzen, and D. T. Lawrence, eds., Deep-water reservoirs of the world: Gulf Coast Section Society of Economic Paleontologists and Mineralogists Foundation, $20^{\text {th }}$ Annual Bob F. Perkins Research Conference, p. 40-60.

Berggren, W. A., D. V. Kent, and J. A. van Couvering, 1985, The Neogene: part 2 Neogene geochronology and chronostratigraphy, in N. J. Snelling, ed., The chronology of the geological record: Geological Society of London Memoir 10, p. 211-260.

Berggren, W. A., F. J. Hilgen, C. G. Langereis, D. V. Kent, J. D. Obradovich, I. Raffi, M. E. Raymo, and N. J. Shackleton, 1995a, Late Neogene chronology: new perspectives in high-resolution stratigraphy: Geological Society of America Bulletin, v. 107, p. 1272-1287.

Berggren, W. A., D. V. Kent, C. C. Swisher, III, and M. P. Aubry, 1995b, A revised Cenozoic geochronology and chronostratigraphy, in W. A. Berggren, D. V. Kent, M. P. Aubry, and J. Hardenbol, eds., Geochronology, time scales, and global 
stratigraphic correlation: Society of Economic Paleontologists and Mineralogists Special Publication 54, p. 129-212.

Bird, D. E., K. Burke, S. A. Hall, and J. F. Casey, 2005, Gulf of Mexico tectonic history: hotspot tracks, crustal boundaries, and early salt distribution: American Association of Petroleum Geologists Bulletin, v. 89, p. 311-328.

Booth, J. R., A. E. DuVernay, III, D. S. Pfeiffer, and M. J. Styzen, 2000, Sequence stratigraphic framework, depositional models, and stacking patters of ponded and slope fan systems in the Auger basin, in P. Weimer, R. M. Slatt, J. Coleman, N. C. Rosen, H. Nelson, A. H. Bouma, M. J. Styzen, and D. T. Lawrence, eds., Deepwater reservoirs of the world: Gulf Coast Section Society of Economic Paleontologists and Mineralogists Foundation, $20^{\text {th }}$ Annual Bob F. Perkins Research Conference, p. 82-103.

Booth, J. R., M. C. Dean, A. E. DuVernay, III, and M. J. Styzen, 2003, Paleo-bathymetric controls on the stratigraphic architecture and reservoir development of confined fans in the Auger basin: central Gulf of Mexico slope: Marine and Petroleum Geology, v. 20, p. 563-586.

Brown, A. R., C. G. Dahm, and R. J. Graebner, 1981, A stratigraphic case history using three-dimensional seismic data in the Gulf of Thailand: Geophysical Prospecting, v. 29, p. 327-349.

Buffler, R. T., and D. S. Sawyer, 1985, Distribution of crust and early history, Gulf of Mexico basin: Gulf Coast Association of Geological Societies Transactions, v. 35, p. 333-344.

Canals, M., P. Puig, X. Durrieu de Madron, S. Heussner, A. Palanques, and J. Fabres, 2006, Flushing submarine canyons: Nature, v. 444, p. 354-357.

Carbotte, S. M., R. Arko, D. N. Chayes, W. Haxby, K. Lehnert, S. O’Hara, W. B. F. Ryan, R. A. Weissel, T. Shipley, L. Gahagan, K. Johnson, T. Shank, 2004, New integrated data management system for Ridge2000 and MARGINS research: EOS, v. 85, p. 553, 559.

Catuneanu, O., 2002, Sequence stratigraphy of clastic systems: concepts, merits, and pitfalls: Journal of African Earth Sciences, v. 35, p. 1-43.

Catuneanu, O., 2006, Principles of Sequence Stratigraphy: Amsterdam, Elsevier, 375 p.

Catuneanu, O., W. E. Galloway, C. G. St C. Kendall, A. D. Miall, H. W. Posamentier, A. Strasser, and M. E. Tucker, 2011, Sequence stratigraphy: methodology and nomenclature: Newsletters on Stratigraphy, v. 44, p. 173-245. 
Chaisson, W. P., and P. N. Pearson, 1997, Planktonic foraminifer biostratigraphy at site 925: middle Miocene-Pleistocene, in N. J. Shackleton, W. B. Curry, C. Richter, and T. J. Brawler, eds., Proceedings of the Ocean Drilling Program, Scientific Results, 154: College Station, TX (Ocean Drilling Program), p. 3-31.

Chaproniere, G. C. H., M. J. Styzen, W. W. Sager, H. Nishi, P. J. Quinterno, and N. Abrahamsen, 1994, Late Neogene biostratigraphic and magnetostratigraphic synthesis, Leg 135, in J. Hawkins, L. Parson, J. Allan, et al., eds., Proceedings of the Ocean Drilling Program, Scientific Results, 135: College Station, TX (Ocean Drilling Program), p. 857-877.

Cohen, K. M., S. C. Finney, P. L. Gibbard, and J. X. Fan, 2013, The ICS International Chronostratigraphic Chart, Episodes 36, p. 199-204.

Deptuck, M. E., G. S. Steffens, M. Barton, and C. Pirmez, 2003, Architecture and evolution of upper fan channel-belts on the Niger Delta slope and in the Arabian Sea: Marine and Petroleum Geology, v. 20, p. 649-676.

Deptuck, M. E., Z. Sylvester, C. Pirmez, and C. O'Byrne, 2007, Migration-aggradation history and 3-D seismic geomorphology of submarine channels in the Pleistocene Benin-major Canyon, western Niger Delta slope: Marine and Petroleum Geology, v. 24, p. $406-433$.

Diegel, F. A., J. F. Karlo, D. C. Schuster, R. C. Shoup, and P. R. Tauvers, 1995, Cenozoic structural evolution and tectono-stratigraphic framework of the northern Gulf Coast continental margin, in M. P. A. Jackson, D. G. Roberts, and S. Snelson, eds., Salt tectonics: a global perspective: American Association of Petroleum Geologists Memoir 65, p. 109-151.

Edwards, B. D., H. J. Lee, and M. E. Field, 1995, Mudflow generated by retrogressive slope failure, Santa Barbara basin, California continental borderland: Journal of Sedimentary Research, v. A65, p. 57-68.

Expedition 308 Scientists, 2005, Overpressure and fluid flow processes in the deepwater Gulf of Mexico: slope stability, seeps, and shallow-water flow: Integrated Ocean Drilling Program Preliminary Report 308.

Feng, J., R. T. Buffler, and M. A. Kominz, 1994, Laramide orogenic influence on late Mesozoic-Cenozoic subsidence history, western deep Gulf of Mexico basin: Geology, v. 22, p. 359-362.

Flores, J. A., and M. Marino, 2002, Pleistocene calcareous nannofossil stratigraphy for the ODP Leg 177 (Atlantic sector of the Southern Ocean): Marine Micropaleontology, v. 45, p. 191-224. 
Gee, M. J. R., R. L. Gawthorpe, and S. J. Friedmann, 2006, Triggering and evolution of a giant submarine landslide, offshore Angola, revealed by 3D seismic stratigraphy and geomorphology: Journal of Sedimentary Research, v. 76, p. 9-19.

Galloway, W. E., 2001, Cenozoic evolution of sediment accumulation in deltaic and shore-zone depositional systems, northern Gulf of Mexico basin: Marine and Petroleum Geology, v. 18, p. 1031-1040.

Galloway, W. E., P. E. Ganey-Curry, X. Li, and R. T. Buffler, 2000, Cenozoic depositional history of the Gulf of Mexico basin: American Association of Petroleum Geologists Bulletin, v. 84, p. 1743-1774.

Galloway, W. E., S. Mentemeier, M. Rowan, and L. M. Gochioco, 2004, Plumbing the depths of the Gulf of Mexico: recent understanding of Cenozoic sand dispersal systems and ultradeep reservoir potential: The Leading Edge, v. 23, p. 44-51.

Galloway, W. E., T. L. Whiteaker, and P. Ganey-Curry, 2011, History of Cenozoic North American drainage basin evolution, sediment yield, and accumulation in the Gulf of Mexico basin: Geosphere, v. 7, p. 938-973.

Gard, G., 1988, Late Quaternary calcareous nannofossil biozonation, chronology and palaeo-oceanography in areas north of the Faeroe-Iceland Ridge: Quaternary Science Reviews, v. 7, p. 65-78.

Haddad, S. and M. Cribbs, 2002, Determining reservoir stratigraphic continuity via well testing in deepwater Gulf of Mexico, Fuji prospect: Society of Petroleum Engineers Annual Technical Conference and Exhibition, 29 September - 2 October, 2002, San Antonio, Texas, p. 1-13.

Haflidason, H., H. P. Sejrup, A. Nygård, J. Mienert, P. Bryn, R. Lien, C. F. Forsberg, K. Berg, and D. Masson, 2004, The Storegga Slide: architecture, geometry and slide development: Marine Geology, v. 213, p. 201-234.

Haflidason, H., R. Lien, H. P. Sejrup, C. F. Forsberg, and P. Bryn, 2005, The dating and morphology of the Storegga Slide: Marine and Petroleum Geology, v. 22, p. 123136.

Haq, B. U., J. Hardenbol, and P. R. Vail, 1987, Chronology of fluctuating sea levels since the Triassic: Science, v. 235 p. 1156-1167.

Haq, B. U., J. Hardenbol, and P. R. Vail, 1988, Mesozoic and Cenozoic chronostratigraphy and cycles of sea-level change, in C. K. Wilgus, B. S. Hastings, C. G. St. C. Kendall, H. W. Posamentier, C. A. Ross, and J. C. Van 
Wagoner, eds., Sea level changes - an integrated approach: Society of Economic Paleontologists and Mineralogists Special Publication 42, p. 71-108.

Harris, P. T., T. Whiteway, 2011, Global distribution of large submarine canyons: Geomorphic differences between active and passive continental margins: Marine Geology, v. 285, p. 69-86.

Hart, B. S., Sibley, D. M., and Flemings, P. B., 1997, Seismic stratigraphy, facies architecture, and reservoir character of a Pleistocene shelf-margin delta complex, Eugene Island Block 330 Field, offshore Louisiana: American Association of Petroleum Geologists Bulletin p. 81, 380-397.

Hine, N. and P. P. E Weaver, 1998, Quaternary, in P. R. Bown, ed., Calcareous Nannofossil Biostratigraphy: British Micropalaeontological Society Publications Series, p. 266-283.

Imran, J., G. Parker, N. Katopodes, 1998, A numerical model of channel inception on submarine fans: Journal of Geophysical Research, v. 103, p. 1219-1238.

Jenner, K. A., D. J. W. Piper, D. Calvin Campbell, and D. C. Mosher, 2007, Lithofacies and origin of late Quaternary mass transport deposits in submarine canyons, central Scotian slope, Canada: Sedimentology, v. 54, 19-38.

Jervey, M. T., 1988, Quantitative geological modelling of siliciclastic rock sequences and their seismic expression, in C. K. Wilgus, B. S. Hastings, C. G. St. C. Kendall, H. W. Posamentier, C. A. Ross, and J. C. Van Wagoner, eds., Sea level changes - an integrated approach: Society of Economic Paleontologists and Mineralogists Special Publication 42, p. 47-69.

Kennett, J. P., K. Elmstrom, and N. Penrose, 1985, The last deglaciation in Orca basin, Gulf of Mexico: High-resolution planktonic foraminiferal changes: Palaeogeography, Palaeoclimatology, Palaeoecology, v. 50, p. 189-216.

Knappertsbusch, M., 2000, Morphologic evolution of the coccolithophorid Calcidiscus leptoporus from the early Miocene to recent: Journal of Paleontology, v. 74, p. 712-730.

Kolla, V., P., Biondi, B. Long, and R. Fillon, 2000, Sequence stratigraphy and architecture of the Late Pleistocene Lagniappe delta complex, northeast Gulf of Mexico, in D. Hunt, and R. L. Gawthorpe, eds., Sedimentary responses to forced regressions: Geological Society, London, Special Publications 172, p. 291-327. 
Kolla, V., and M. A. Perlmutter, 1993, Timing of turbidite sedimentation on the Mississippi Fan: American Association of Petroleum Geologists Bulletin, v. 77, p. 1129-1141.

Kolla, V., H. W. Posamentier, and L. J. Wood, 2007, Deep-water and fluvial sinuous channels - characteristics, similarities and dissimilarities, and modes of formation: Marine and Petroleum Geology, v. 24, p. 388-405.

Lee, C., J. A. Nott, and F. B. Keller, 2004, Seismic expression of the Cenozoic mass transport complexes, deepwater Tarfaya-Agadir basin, offshore Morocco: Annual Offshore Technology Conference, Houston, Texas, OTC Paper 16741, p. 1-18.

Lourens, L. J., F. J. Hilgen, I. Raffi, and C. Vergnaud-Grazzini, 1996, Early Pleistocene chronology of the Vrica section (Calabrai, Italy): Paleoceanography, v. 11, p. 797812.

Lourens, L., F. Hilgen, N. J. Shackleton, J. Laskar, and J. Wilson, 2004, Appendix 2 Orbital tuning calibrations and conversions for the Neogene Period, in F. M. Gradstein, J. G. Ogg, and A. G. Smith, eds., A geologic time scale 2004: Cambridge, Cambridge University Press, p. 469-484.

Madof, A. S., 2010, Noneustatic controls on sediment accumulation in the upper Cretaceous of western Colorado and Pliocene to Holocene of offshore Louisiana: Ph.D. dissertation, Columbia University, New York, New York, 207 p.

Madof, A. S., N. Christie-Blick, and M. H. Anders, 2009, Stratigraphic controls on a saltwithdrawal intraslope minibasin, north-central Green Canyon, Gulf of Mexico: implications for misinterpreting sea level change: American Association of Petroleum Geologists Bulletin, v. 93, p. 535-561.

Madof, A. S., A. D. Harris, and S. D. Connell, 2016, Nearshore along-strike variability: Is the concept of the systems tract unhinged?: Geology, v. 44, p. 315-318.

Mallarino, G., R. T. Beaubouef, A. W. Droxler, V. Abreu, and L. Labeyrie, 2006, Sea level influence on the nature and timing of a minibasin sedimentary fill (northwestern slope of the Gulf of Mexico): American Association of Petroleum Geologists Bulletin, v. 90, p. 1089-1119.

Marine Geoscience Data System, 2008, Explore our planet with GeoMapApp: LamontDoherty Earth Observatory, Columbia University, New York: <http://www.geomapapp.org>, accessed December 4, 2007. 
Marine Geoscience Data System, 2009, Explore our planet with Virtual Ocean: LamontDoherty Earth Observatory, Columbia University, New York: <http://www.virtualocean.org>, accessed September 20, 2009.

Martinez, J. F., J. Cartwright, and B. Hall, 2005, 3D seismic interpretation of slump complexes: examples from the continental margin of Israel: Basin Research, v. 17 , p. 83-108.

McBride, B. C., 1997, The geometry and evolution of allochthonous salt and its impact on petroleum systems, northern Gulf of Mexico basin, studies in three- and fourdimensional analysis: Ph.D. dissertation, University of Colorado, Boulder, Colorado, $276 \mathrm{p}$.

McBride, B. C., P. Weimer, and M. G. Rowan, 1998, The effect of allochthonous salt on the petroleum systems of northern Green Canyon and Ewing Bank (offshore Louisiana), northern Gulf of Mexico: American Association of Petroleum Geologists Bulletin, v. 82, p. 1083-1112.

McHargue, T., M. J. Pyrcz, M. D. Sullivan, J. Clark., A. Fildani, B. R. Romans, J. A. Covault, M. Levy, H. Posamentier, and N. Drinkwater, 2011, Architecture of turbidite channel systems on the continental slope: patterns and predictions: Marine and Petroleum Geology, v. 28, p. 728-743.

McHugh, C. M. G., J. E. Damuth, and G. S. Mountain, 2002, Cenozoic mass-transport facies and their correlation with relative sea-level change, New Jersey continental margin: Marine Geology, v. 184, p. 295-334.

Miller, K. G., M. A. Kominz, J. V. Browning, J. D. Wright, G. S. Mountain, M. E. Katz, P. J. Sugarman, B. S. Cramer, N. Christie-Blick, and S. F. Pekar, 2005, The Phanerozoic record of global sea-level change: Science, v. 301, p. 1293-1298.

Mitchum, R. M. Jr., P. R. Vail, and J. B. Sangree, 1977, Seismic stratigraphy and global changes of sea level, part 6: stratigraphic interpretation of seismic reflection patterns in depositional sequences, in C. W. Payton, ed., Seismic stratigraphy applications to hydrocarbon exploration: American Association of Petroleum Geologists Memoir 26, p. 117-134.

Mohrig, D., K. X. Whipple, M. Hondzo, C. Ellis, and G. Parker, 1998, Hydroplaning of subaqueous debris flows: Geological Society of America, Bulletin, v. 110, p. 387394.

Moscardelli, L. and L. Wood, 2008, New classification system for mass transport complexes in offshore Trinidad: Basin Research, v. 20, p. 73-98. 
Moscardelli, L., L. Wood, and P. Mann, 2006, Mass-transport complexes and associated processes in the offshore area of Trinidad and Venezuela: American Association of Petroleum Geologists Bulletin, v. 90, p. 1059-1088.

Mulder, T., and P. Cochonat, 1996, Classification of offshore mass movements: Journal of Sedimentary Research, v. 66, p. 43-57.

Ogata, K., G. A. Pini, A. Festa, Ž. Pogačnik, G. Tunis, J. J. Mountjoy, K. Senger, and M. Strasser, 2014, High-resolution studies of mass transport deposits: outcrop perspective for understanding modern submarine slope failure and associated natural hazards, in G. Lollino, A. Manconi, J. Locat, Y. Huang, and M. Canals Artigas, eds., Engineering Geology for Society and Territory - Volume 4: Marine and Coastal Process, p. 209-213.

Patruno, S., G. J. Hampson, and C. A.-L. Jackson, 2015, Quantitative characterisation of deltaic and subaqueous clinoforms: Earth-Science Reviews, v. 142, p. 79-119.

Peakall, J., B. McCaffrey, and B. Kneller, 2000a, A process model for the evolution, morphology and architecture of sinuous submarine channels: Journal of Sedimentary Research, v. 70, p. 434-448.

Peakall, J., W. D. McCaffrey, B. C. Kneller, C. E. Stelting, T. R. McHargue, and W. J. Schweller, 2000b, A process model for the evolution of submarine fan channels: implications for sedimentary architecture, in A. H. Bouma and C. G. Stone, eds., Fine-grained turbidite systems: American Association of Petroleum Geologists Memoir 72, p. 73-87.

Pickering, K. T., and J. Corregidor, 2005, Mass-transport complexes (MTCs) and tectonic control on basin-floor submarine fans, middle Eocene, south Spanish Pyrenees: Journal of Sedimentary Research, v. 75, p. 761-783.

Pindell, J. L., L. Kennan, 2009, Tectonic evolution of the Gulf of Mexico, Caribbean and northern South America in the mantle reference frame: an update, in K. H. James, M. A. Lorente, J. L. Pindell, eds., The Origin and Evolution of the Caribbean Plate: Geological Society, London, Special Publications, 328, p. 1-55.

Poore, R. Z., L. Tauxe, S. F. Percival, Jr., J. L. Labrecque, R. Wright, N. P. Petersen, C. C. Smith, P. Tucker, and K. J. Hsu, 1983, Late Cretaceous-Cenozoic magnetostratigraphic and biostratigraphic correlations of the south Atlantic Ocean: DSDP Leg 73: Palaeogeography, Palaeoclimatology, Palaecology, v. 42, p. 127-149. 
Posamentier, H. W., 2003, Depositional elements associated with a basin floor channellevee system: case study from the Gulf of Mexico: Marine and Petroleum Geology, v. 20, p. 677-690.

Posamentier, H. W., and G. P. Allen, 1999, Siliciclastic sequence stratigraphy - concepts and applications: Society of Economic Paleontologists and Mineralogists Concepts in Sedimentology and Paleontology \#7, 204 p.

Posamentier, H. W., and V. Kolla, 2003, Seismic geomorphology and stratigraphy of depositional elements in deep-water settings: Journal of Sedimentary Research, v. 73 , p. 367-388.

Posamentier, H. W., and P. R. Vail, 1988, Eustatic controls on clastic deposition II sequence and systems tract models, in C. K. Wilgus, B. S. Hastings, C. G. St. C. Kendall, H. W. Posamentier, C. A. Ross, and J. C. Van Wagoner, eds., Sea level changes - an integrated approach: Society of Economic Paleontologists and Mineralogists Special Publication 42, p. 125-154.

Posamentier, H. W., D. P. James, and G. P. Allen, 1990, Aspects of sequence stratigraphy: Recent and ancient examples of forced regressions [Abstract]: American Association of Petroleum Geologists, Annual Convention, San Francisco, 3-6 June 1990, 1 p.

Posamentier, H. W., M. T. Jervey, and P. R. Vail, 1988, Eustatic controls on clastic deposition I - conceptual framework, in C. K. Wilgus, B. S. Hastings, C. G. St. C. Kendall, H. W. Posamentier, C. A. Ross, and J. C. Van Wagoner, eds., Sea level changes - an integrated approach: Society of Economic Paleontologists and Mineralogists Special Publication 42, p. 109-124.

Posamentier, H. W., A. S. Madof, S. C. Lang, K. D. Ehman, and O. Bakare, 2014, Integration of seismic stratigraphy and seismic geomorphology for prediction of lithology - applications and workflows [Abstract]: European Association of Geoscientists Engineers, International Geophysical Conference and Exhibition, Saint Petersburg, Russia, 11-14 August 2014, 5 p.

Prather, B. E., J. R. Booth, G. S. Steffens, and P. A. Craig, 1998, Classification, lithologic calibration, and stratigraphic succession of seismic facies of intraslope basins, deep-water Gulf of Mexico: American Association of Petroleum Geologists Bulletin, v. 82, p. 701-728.

Prather, B. E., C. Pirmez, and C. Winker, 2012, Stratigraphy of linked intraslope basins: Brazos-Trinity system western Gulf of Mexico, in B. E. Prather, M. E. Deptuck, D. Mohrig, B. Van Hoorn, and R. B. Wynne, eds., Application of the principles of seismic geomorphology to continental-slope and base-of-slope systems: case 
studies from seafloor and near-surface analogues: Society of Economic Paleontologists and Mineralogists Special Publication 99, p. 83-109.

Pratson, L. F., W. B. F. Ryan, G. S. Mountain, and D. C. Twichell, 1994, Submarine canyon initiation by downslope-eroding sediment flows: evidence in late Cenozoic strata on the New Jersey continental slope: Geological Society of America Bulletin, v. 106, p. 395-412.

Pratson, L. F. and B. J. Coakley, 1996, A model for the headward erosion of submarine canyons induced by downslope-eroding sediment flows: Geological Society of America Bulletin, v. 108, p. 225-234.

Quinn, M. J., 2005, The impact of increasing accommodation on sediment deposition and hydrocarbon accumulation in the greater Ship Shoal area: Gulf Coast Association of Geological Societies Transactions, v. 55, p. 675-688.

Quinn, M. J., 2006, No Guts, no glory - two recent discoveries in stratigraphically controlled upper Miocene/lower Pliocene sands in Ship Shoal 181 and 194/206: Gulf Coast Association of Geological Societies Transactions, v. 56, p. 701-715.

Raffi, I., and J. A. Flores, 1995, Pleistocene through Miocene calcareous nannofossils from eastern equatorial Pacific Ocean (Leg 138), in N. G. Pisias, L. A. Mayer, T. R. Janecek, A. Palmer-Julson, and T. H. van Andel, eds., Proceeding of the Ocean Drilling Program, Scientific Results, 138: College Station, TX (Ocean Drilling Program), p. 233-286.

Ragaini, L., C. Di Celma, and G. Cantalamessa, 2008, Warm-water mollusc assemblages from northern Chile (Mejillones Peninsula): new evidence for permanent El Niñolike conditions during Pliocene warmth?: Journal of the Geological Society, London, v. 165, p. 1075-1084.

Roof, S. R., H. T. Mullins, S. Gartner, T. C. Huang, E. Joyce, J. Prutzman, and L. Tjalsma, 1991, Climatic forcing of cyclic carbonate sedimentation during the last 5.4 million years along the west Florida continental margin: Journal of Sedimentary Petrology, v. 61, p. 1070-1088.

Saller, A. H., J. T. Noah, A. P. Ruzuar, and R. Schneider, 2004, Linked lowstand delta to basin-floor fan deposition, offshore Indonesia: an analog for deep-water reservoir systems: American Association of Petroleum Geologists Bulletin, v. 88, p. 21-46.

Salvador, A., 1987, Late Triassic-Jurassic paleogeography and origin of Gulf of Mexico basin: American Association of Petroleum Geologists Bulletin, v. 71, p. 419-451. 
Salvador, A., 1991, Origin and development of the Gulf of Mexico basin, in A. Salvador, ed., The Gulf of Mexico basin: Geological Society of America, p. 389-444.

Sandwell, D. T., R. D. Müller, W. H. F. Smith, E. Garcia, and R. Francis, 2014, New global marine gravity model for CryoSat-2 and Jason-1 reveals buried tectonic structure: Science, v. 346, p. 65-67.

Satterfield, W. M., and E. W. Behrens, 1990, A late Quaternary canyon/channel system, northwest Gulf of Mexico continental slope: Marine Geology, v. 92, p. 51-67.

Shipboard Scientific Party, 1995, Leg 154 synthesis, in W. B. Curry, N. J. Shackleton, C. Richter, et al., eds., Proceedings of the Ocean Drilling Program, Initial Reports, 154: College Station, TX (Ocean Drilling Program), p. 421-442.

Soto, G., 1997, 3-D seismic stratigraphic interpretation of Pleistocene sediments, Fuji mini-basin, central Green Canyon, northern deep Gulf of Mexico, Masters thesis, University of Colorado, Boulder, Colorado, 176 p.

Sylvester, Z., A. Cantelli, and C. Pirmez, 2015, Stratigraphic evolution of intraslope minibasins: insights from surface-based model: American Association of Petroleum Geologists, v. 99, p. 1099-1129.

Tesson, M., H. W. Posamentier, and B. Gensous, 2000, Stratigraphic organization of late Pleistocene deposits of the western part of the Golfe du Lion shelf (Languedoc shelf), western Mediterranean Sea, using high-resolution seismic and core data: American Association of Petroleum Geologists Bulletin, v. 84, p. 119-150.

Thierstein, H. R., K. R. Geitzenauer, B. Molfino, and N. J. Shackleton, 1977, Global synchroneity of late Quaternary coccolith datum levels: validation by oxygen isotopes: Geology, v. 5, p. 400-404.

Tripsanas, E. K., D. J. W. Piper, K. A. Jenner, and W. R. Bryant, 2008, Submarine masstransport facies: new perspectives on flow processes from cores on the eastern North American margin: Sedimentology, v. 55, p. 97-136.

Vail, P. R., 1987, Seismic stratigraphy interpretation using sequence stratigraphy, in A. W. Bally, ed., Atlas of seismic stratigraphy: American Association of Petroleum Geologists Studies in Geology 27, p. 1-10.

Vail, P. R., R. M. Mitchum, Jr., and S. Thompson, III, 1977, Seismic stratigraphy and global changes of sea level, part 4: global cycles of relative changes of sea level, in C. W. Payton, ed., Seismic stratigraphy - applications to hydrocarbon exploration: American Association of Petroleum Geologists Memoir 26, p. 83-97. 
Varnai, P., 1998, Three-dimensional seismic stratigraphic expression of PliocenePleistocene turbidite systems, northern Green Canyon (offshore Louisiana), northern Gulf of Mexico: American Association of Petroleum Geologists, v. 82, p. 986-1012.

Waterman, A. S., M. W. Center, R. A. George, N. S. Vallette, A. F. Porter, Jr., T. M. Reilly, R. A. Weber, R. V. Roederer, and R. H, Fillon , 2009, Biostratigraphic chart, Gulf basin, USA, Neogene: Paleo-Data, Inc., New Orleans: $\langle\mathrm{http}: / /$ www.paleodata.com/downloads/PDIneogene.pdf $>$, accessed December 3, 2009.

Weimer, P., 1990, Sequence stratigraphy, facies geometries, and depositional history of the Mississippi Fan, Gulf of Mexico: American Association of Petroleum Geologists Bulletin, v. 74, p. 425-453.

Weimer, P., J. R. Crews, R. S. Crow, and P. Varnai, 1998, Atlas of petroleum fields and discoveries, northern Green Canyon, Ewing Bank, and southern Ship Shoal and South Timbalier areas (offshore Louisiana), northern Gulf of Mexico: American Association of Petroleum Geologists Bulletin, v. 82, p. 878-917.

Wilson, J. L., 1967, Cyclic and reciprocal sedimentation in Virgilian strata of southern New Mexico: Geological Society of American Bulletin, v. 78, p. 805-818.

Winker, C. D., and J. R. Booth, 2000, Sedimentary dynamics of the salt-dominated continental slope, Gulf of Mexico: integration of observations from the seafloor, nearsurface, and deep subsurface, in P. Weimer, R. M. Slatt, J. Coleman, N. C. Rosen, H. Nelson, A. H. Bouma, M. J. Styzen, and D. T. Lawrence, eds., Deepwater reservoirs of the world: Gulf Coast Section Society of Economic Paleontologists and Mineralogists Foundation, $20^{\text {th }}$ Annual Bob F. Perkins Research Conference, p. 1059-1086.

Witrock, R. B., A. R. Friedmann, J. J. Galluzzo, L. D. Nixon, P. J. Post, and K. M. Ross, 2003, Biostratigraphic chart of the Gulf of Mexico offshore region, Jurassic to Quaternary: U. S. Department of the Interior, Minerals Management Service, New Orleans, <http://www.gomr.mms.gov/homepg/whatsnew/papers/biochart.pdf>, accessed December 21, 2006.

Woock, R. D., and A. R. Kin, 1987, Predictive isopach mapping of gas sands from seismic impedance: modelled and empirical cases from Ship Shoal Block 134 Field: American Association of Petroleum Geologists Bulletin, v. 71, p. 11431151. 
Zeng, H., M. M. Backus, K. T. Barrow, and N. Tyler, 1995, Three dimensional seismic modeling and seismic facies imaging: Gulf Coast Association of Geologic Societies Transactions, v. 45, p. 621-628.

Zeng, H., and T. F. Hentz, 2004, High-frequency sequence stratigraphy from seismic sedimentology: applied to Miocene, Vermilion Block 50, Tiger Shoal area, offshore Louisiana: American Association of Petroleum Geologists Geologic Note, v. 88, p. 153-174.

Zhang, J., and J. S. Watkins, 1994, Plio-Pleistocene structural characteristics of central offshore Louisiana with emphasis on growth-fault interplay with salt tectonics, Gulf of Mexico: Gulf Coast Association of Geological Societies Transactions, v. 44, p. $745-754$. 


\section{List of figures}

Figure 1 - Map illustrating salt-withdrawal intraslope minibasins, Pleistocene paleogeographic features, and selected datasets from the Gulf of Mexico. Solid white lines (onshore) show rivers, dashed black line (offshore) approximates shelf-slope break, and solid black line (offshore) delineates Sigsbee Escarpment. Pleistocene features (from Winker and Booth, 2000) are abbreviated as follows. Shelf margin deltas: RD = Rio Grande, $\mathrm{CD}=$ Colorado, $\mathrm{BTD}=$ Brazos-Trinity, $\mathrm{MDW}=$ Mississippi Western, $\mathrm{MDE}=$ Mississippi Eastern. Submarine canyons: $\mathrm{PC}=$ Perdido, $\mathrm{AC}=$ Alaminos, $\mathrm{KC}=$ Keathley, $\mathrm{BC}=$ Bryant, $\mathrm{MC}=$ Mississippi. Submarine fans: $\mathrm{RF}=$ Rio Grande $\mathrm{CF}=$ Colorado, $\mathrm{BTF}$ $=$ Brazos-Trinity, $\mathrm{AF}=$ Alaminos, $\mathrm{BF}=$ Bryant. Seismic data used for this study are shown in blue (2-D) and red (3-D); additional datasets shown are from Anderson et al., 2004 (black lines), Kolla et al., 2000 (white lines), and Hart et al., 1997 (black square).

Figure 2 - Location maps of study area. A) Distribution of 2-D and 3-D seismic data superimposed over bathymetric map, with artificial light from the west (created using GeoMapApp, Marine Geoscience Data System, 2008; see Carbotte et al., 2004). Bureau of Ocean Energy Management (BOEM) protraction areas are delineated by gray lines, and are abbreviated as follows: $\mathrm{SP}=$ South Pelto, $\mathrm{SS}=$ Ship Shoal, $\mathrm{ST}$ and BM = South Timbalier and Bay Marchand, SSSA = Ship Shoal South Addition, STSA = South Timbalier South Addition, EB = Ewing Bank, GC = Green Canyon. B) Bathymetric map created on sea-floor reflection from 3-D survey. Map shows salt-controlled structural high (white) separating Fuji basin (west) from linked Mazama-Hornet basins (east). 
Dashed line delineates extent of volume used in Madof et al. (2009). The four wells displayed have age control, and were used as a supplement to regional biostratigraphic horizons; the GC 506 Texaco 1 well also has core, logs, and checkshot data (see Figures 3 and 4). Artificial light is directly overhead. TWTT = two-way travel time. Modified from Madof (2010).

Figure 3 - Seismic section and well log from southern study area. The GC 506 Texaco 1 well is located in Fuji basin (see Figure 2B for location; Soto, 1997). A) Vertical seismic section showing Fuji and Mazama basins. Seismic data courtesy of CGG-Veritas. B) Gamma ray (GR) and resistivity (R) logs for the GC 506 Texaco 1 well. Core (black intervals) taken from 17,948-18,034 ft, 18,084-18,178 ft, and 19,078-19,106 ft was used to calibrate GR log, based on a 70 API linear shale cutoff (dotted line).

Figure 4 - Time-to-depth plot and interval velocity curve from check shot of GC 506 Texaco 1 well (from Soto, 1997). A) Time-to-depth plot is relatively consistent, and approximates a linear relationship (dotted line). The slope of the line, which is the equation for the average velocity, shows more consistency than the interval velocity. B) Interval velocity showing variability, and especially with increasing depth. P-wave velocity $(\mathrm{Vp})$ of seawater is assumed to be $1,500 \mathrm{~m} / \mathrm{s}$.

Figure 5 - Summary of 2-D and 3-D seismic data from study area. A and D) Frequencyamplitude spectra for 2-D and 3-D data with respect to depth (in TWTT). Note that 
bandwidth is higher in 3-D data (see Table 1). B and E) Sea floor reflection displaying polarity. C and F) Plots showing vertical wavelength, limit of separability, and limit of detectability with depth.

Figure 6 - Conceptual diagram illustrating correlation lengths obtained via tracing reflections (A) versus using biostratigraphy (B). Reflections in the Gulf of Mexico are discontinuous over distances greater than tens of kilometers (A). Establishing a regional time-stratigraphic framework (B) therefore requires the use of biostratigraphic datums (orange), which are continuous of over hundreds of kilometers. See Figure 7 for legend.

Figure 7 - North-south oriented seismic profile (see Figure 2A for location) showing distribution of facies and age control. Seismic section extends from the shelf (left) to slope (right), and intersects Fuji basin (Figure 9). A) Uninterpreted 2-D seismic profile, showing notable and widespread reflection discontinuity. Note that reflections also lack continuity away from structures. TWTT = two-way travel time. B) Age control and structure within study area. Biostratigraphic datums established below modern shelf correspond to last occurrences of Angulogerina B ( $\geq 1.5 \mathrm{Ma})$, G. multicamerata $(\geq 2.9$ Ma), P. obliquiloculata $(\geq 3.33 \mathrm{Ma})$, and A.tricorniculatus $(\geq 3.7 \mathrm{Ma})$, while those obtained within slope correspond to last occurrences of Globorotalia inflata $(\geq 0.0105$ Ma), P. lacunosa ( $\geq 0.45 \mathrm{M})$, S. antillea ( $\geq 0.78 \mathrm{Ma}), H$. balthica $(\geq 1.22 \mathrm{Ma})$, and $D$. brouweri ( $\geq 1.89 \mathrm{Ma})$. C) Interpreted structure, stratigraphic geometry, and facies. Note that MTCs (mass transport complexes) become progressively younger in outboard (slope) 
locations. White lines at base of MTCs signify slumped shelf edge sediments. Modified from Madof (2010). Seismic data courtesy of TGS-Nopec.

Figure 8 - North-south oriented seismic profile showing distribution of facies and age control. Seismic section extends from the shelf (left) to slope (right), and intersects Mazama basin (Figure 10). A) Uninterpreted 2-D seismic section. B) Age control and structure within study area. C) Interpreted structure, stratigraphic geometry, and facies. See Figure 7C for legend. Modified from Madof (2010). Seismic data courtesy of TGSNopec.

Figure 9 - Uninterpreted (top) and interpreted (bottom) north-south oriented seismic profile through Fuji basin (see Figures 2B and 7A for location). Twelve MTCs display an up-section increase in prevalence. Note that MTCs thin towards basin flanks. Black lines identify picked surfaces. Channelized sandy turbidites below $\geq 1.89$ Ma marker $(D$. brouweri) were drilled and found to contain $65.2 \mathrm{~m}$ (214 ft) of oil pay in Green Canyon block 505 (Haddad and Cribbs, 2002). Modified from Madof (2010). Seismic data courtesy of CGG-Veritas.

Figure 10 - Uninterpreted (top) and interpreted (bottom) north-south oriented seismic profile through Mazama basin (see Figures 2B and 8A for location). Twenty MTCs show an up-section increase in frequency. Note that MTCs thin towards basin margins. See 
Figure 9 for legend. Modified from Madof (2010). Seismic data courtesy of CGGVeritas.

Figure 11 - Examples of MTC folds from Mazama basin. A) Horizon slice with extracted amplitude, located internal to MTCs no. 11M and 12M. Amplitude scale applies to entire figure. B) Enlargement of uninterpreted (top) and interpreted (bottom) southern portion of surface, showing axial traces. Blue arrows show interpreted sediment transport direction. C) Uninterpreted (top) and interpreted (bottom) east-west oriented seismic profile. Note position of horizon slice in uninterpreted view. Modified from Madof (2010). Seismic data courtesy of CGG-Veritas.

Figure 12 - Examples of MTC scours from Mazama basin. A) Uninterpreted (left) and interpreted (right) time-structure map of base of MTC no. 8M. B) Uninterpreted (left) and interpreted (right) time-structure map of base of MTC no. 6M. C) Amplitude map of base of MTC no. 4M. D) Enlargement of uninterpreted (left) and interpreted (right) middle portion of surface in C. Blue arrows show interpreted sediment transport direction. E) Amplitude map of base of MTC no. 3M. F) Enlargement of uninterpreted (left) and interpreted (right) southern portion of surface in E. Modified from Madof (2010).

Figure 13 - Distribution of shelf edge sediment facies. Plan view (left) shows extent of offlapping clinoforms (green polygons) and dip direction (white arrows point down gradient). Hachured lines signify slumped shelf edge accumulations. Shelf edge 
sediments are numbered from oldest (no. 5) to youngest (no. 1). Cross-sections

(uninterpreted - middle and interpreted - right) highlight shelf edge sediment no. 1. Amplitude is the same as in Figure 7. Modified from Madof (2010). Seismic data courtesy of TGS-Nopec.

Figure 14 - Distribution of channelized sandy turbidites (map view) within 3-D seismic volume. A) Transparent sea floor superimposed over turbidites at depth. TWTT scale relates to turbidites. Star indicates location of structural sill separating Fuji basin (west) from Mazama-Hornet basins (east). Arrows in B) indicated interpreted trajectory of channelized sandy turbidites in Fuji basin. Modified from Madof (2010).

Figure 15 - Map showing six submarine canyons in northern half of study area. Canyons are numbered from oldest (no. 4) to youngest (no. 1), and become progressively shallower in an eastward direction. Canyons no. 4a and $4 \mathrm{~b}$ underlie no. $3 \mathrm{a}$ and $3 \mathrm{~b}$, respectively, and are truncated by a northeast-trending erosional surface. White arrows indicate interpreted sediment transport. Cross-sections (uninterpreted - middle and interpreted - right) highlight two northernmost canyons (no. 2 and 1), which are composite and amalgamated. Amplitude is the same as in Figure 7. Modified from Madof (2010). Seismic data courtesy of TGS-Nopec.

Figure 16 - Summary of inferred emplacement directions (black arrows) and minimum surface areas (brown polygons) for MTCs in Fuji and Mazama-Hornet basins. Dashed 
arrows indicate a tentative interpretation, while diagonal lines delineate erosion by overlying MTCs. See Table 5 for additional information.

Figure 17 - Summary diagram (from Figure 16) for Fuji and Mazama-Hornet basins showing all interpreted transport directions (arrows), with respect to time (rainbow gradient). Warmer colors indicate older deposits, while cooler colors show younger ones. Note that MTCs within Fuji basin flow radially towards the depocenter, while MTCs in Mazama-Hornet basin primarily flow southward.

Figure 18 - Oblique view (looking north from slope) of modern seafloor, with sourcearea interpretations of MTCs. White stars identify interpreted intrabasinal MTC sources, whereas black stars identify extrabasinal ones. Dashed line approximates shelf-slope break. Artificial lighting is from the south. Vertical exaggeration $=7.5 \mathrm{x}$. Figure made using Virtual Ocean (Marine Geoscience Data System, 2009) accessed on 09-20-2009. Modified from Madof (2010).

Figure 19 - Measured data of MTCs from Fuji and Mazama basins. A and B) Volume of MTC versus number. The majority of MTCs in Fuji are younger than $\sim 0.0105 \mathrm{Ma}$, whereas those in Mazama are younger than 0.45 Ma. Squares represent extrabasinal MTCs, whereas circles show intrabasinal ones. C and D) Histogram of MTCs showing log-normal tendency. Note that smaller MTCs are more prevalent than larger ones. See Table 5 for detailed information. 
Figure 20 - Rose diagrams of directional indicators from MTCs, with interpreted sediment transport directions displayed by blue arrows. A-D) Axial surfaces (folds) from Fuji basin. E-H) Scours marks from Mazama basin. See Table 5 for tabulated data for Mazama basin, and Madof et al. (2009) for data pertaining to Fuji basin. $N=$ population size.

Figure 21 - Sea level curve (i.e., eustasy plus water loading) from Miller et al. (2005). Time scale is from Cohen et al. (2013). * = biostratigraphic datums from slope; $\uparrow=$ biostratigraphic datum from shelf.

Figure 22 - Comparison of fill-and-spill model with our loading-induced passive salt model. A) According to the fill-and-spill model, sedimentation rates are significantly greater than uniform subsidence (black arrows), resulting in the evolution from ponding, to perching, and finally to complete bypass. B) According to our loading-induced passive salt model, accumulation leads to differential subsidence and uplift (large and small arrows) as well as rotated geometries, and the subsequent failure of basin margins. This process results in the generation of intrabasinal MTCs, which precludes preservation of deposits on basin highs. White stars represent intrabasinal MTC source areas.

Figure 23 - East-west oriented seismic profile, showing relationship between depth to salt and MTC generation. See Figure 2B for location. A) Uninterpreted profile. B) 
Interpreted profile showing picked seismic surfaces, salt distribution, and half-turtle structure (delineated by box). At this location, MTCs are interpreted to have been generated from Fuji basin's southeastern margin (white star) but not from the contiguous southwestern flank of Mazama basin (black star). Where thick accumulations exist over basin margins, oversteepening may not be a dominant process. Modified from Madof (2010). Seismic data courtesy of CGG-Veritas.

Figure 24 - Three dimensional models summarizing early Pliocene to Holocene stratigraphic evolution of offshore southern Louisiana. A) and B) Early Pliocene to middle Pleistocene halokinetic cycles ( $\mathrm{A}$ - tectonic quiescence and $\mathrm{B}$ - tectonic activity) create MTCs from intrabasinal and extrabasinal sources. Eastward-oriented yellow arrow (B) is interpreted sediment transport direction for channelized sandy turbidites (see Figure14). C) through E) Middle Pleistocene ( $\sim .45 \mathrm{Ma})$ submarine canyon formation (C) and subsequent infilling (D), followed by backstepping shelf edge sediments (E). F) Middle Pleistocene to Holocene forestepping shelf edge sediments, salt-controlled MTCs, and channelized sandy turbidites. Southward oriented black arrows to north of the modern shelf-slope break (dashed line) indicate progradation directions, while yellow lines to south specify transport directions of channelized sandy turbidites.

Table 1 - Summary of seismic data characteristics for 2-D and 3-D data. Frequency was calculated over a 2,000 ms interval, and bandwidth was measured at half the normalized amplitude (see Figure 5). Velocity was averaged from the GC 506 Texaco 1 well (Figure 
4). Note that detectability was not calculated for 2-D data, as that measurement relates to imaging features in plan view, and solely on 3-D data.

Table 2 - Measurements of clinoforms from 2-D seismic lines. Maximum thickness was calculated by multiplying half of the measurement in milliseconds by interval velocity (Figure 4B). Note that maximum progradation was calculated from extent of observed offlap, and that all clinoforms extend laterally (strike) beyond limit of 2-D data.

Table 3 - Measurements of submarine canyons from 2-D seismic lines. Maximum relief on incision was calculated by multiplying half of the measurement in milliseconds by interval velocity (Figure 4B). Note that canyons show more relief with decreasing age. * $=$ truncated vertically by overlying canyon or erosional edge; $\uparrow=$ eroded laterally by overlying canyon. $1=$ clinoforms; $2=$ contorted hemipelagites; $3=$ muddy turbidites; $4=$ MTCs.

Table 4 - Measurements of MTCs from 3-D seismic volume. Maximum thicknesses were calculated by multiplying half of the measurement in milliseconds by interval velocity (Figure 4B). Volume of MTCs was estimated as wedge shaped, and was therefore calculated by taking product of maximum thickness and minimum surface area divided by $2.1=$ axial surface; $2=$ basal erosion; $3=$ head scarp; $4=\operatorname{scours} ; 5=$ thinning directions. 
Table 5 - Measured trends of basal scours from Figure 12. 


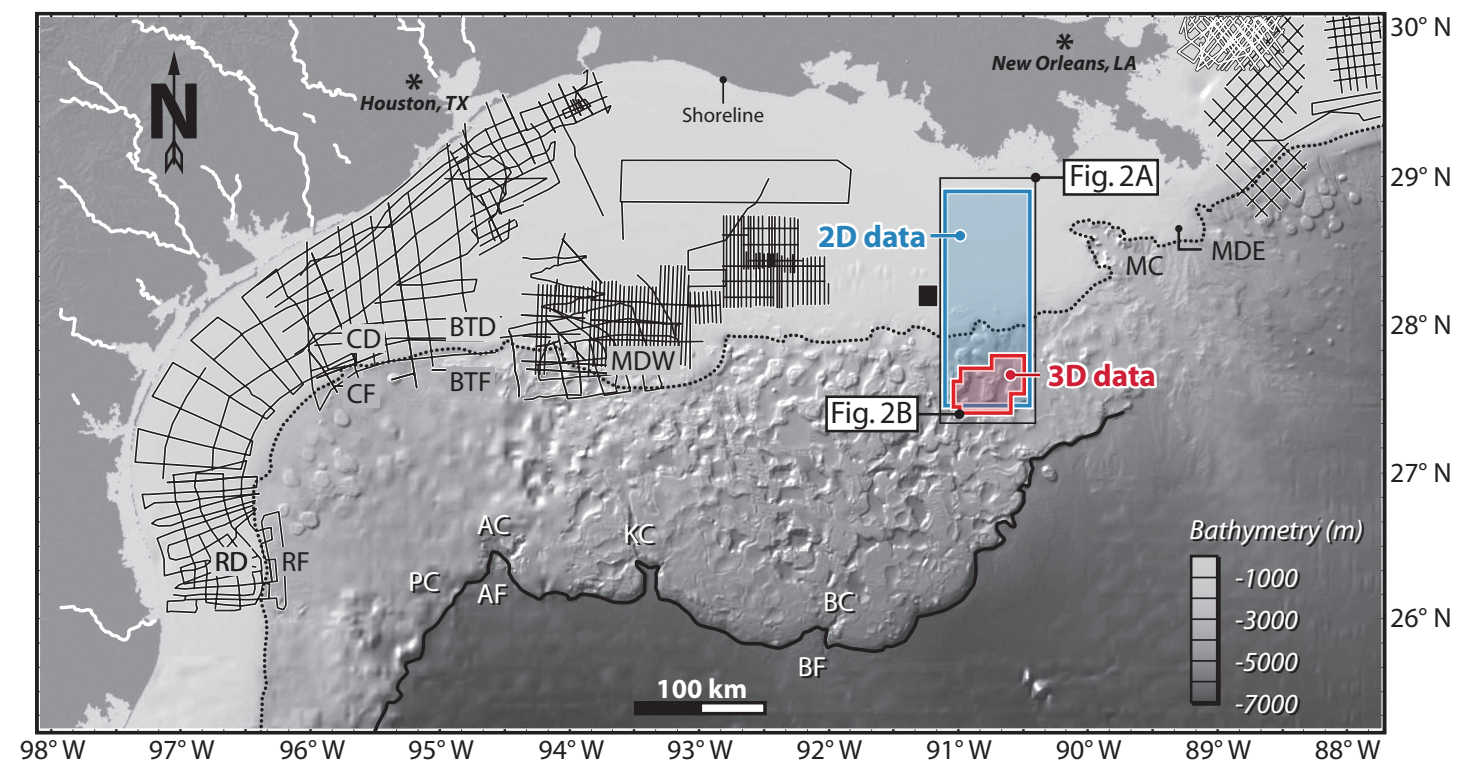

Figure 1 


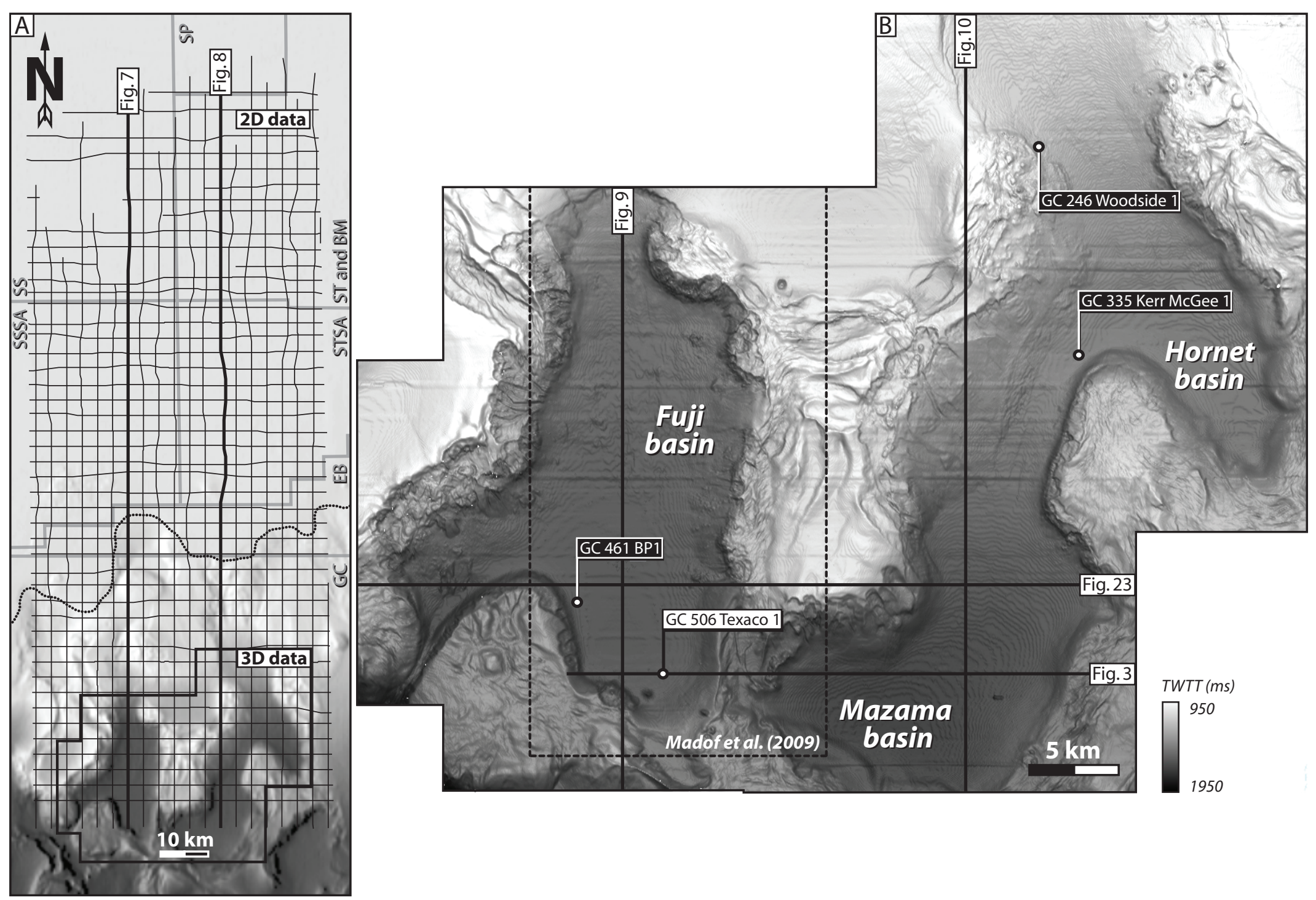


A

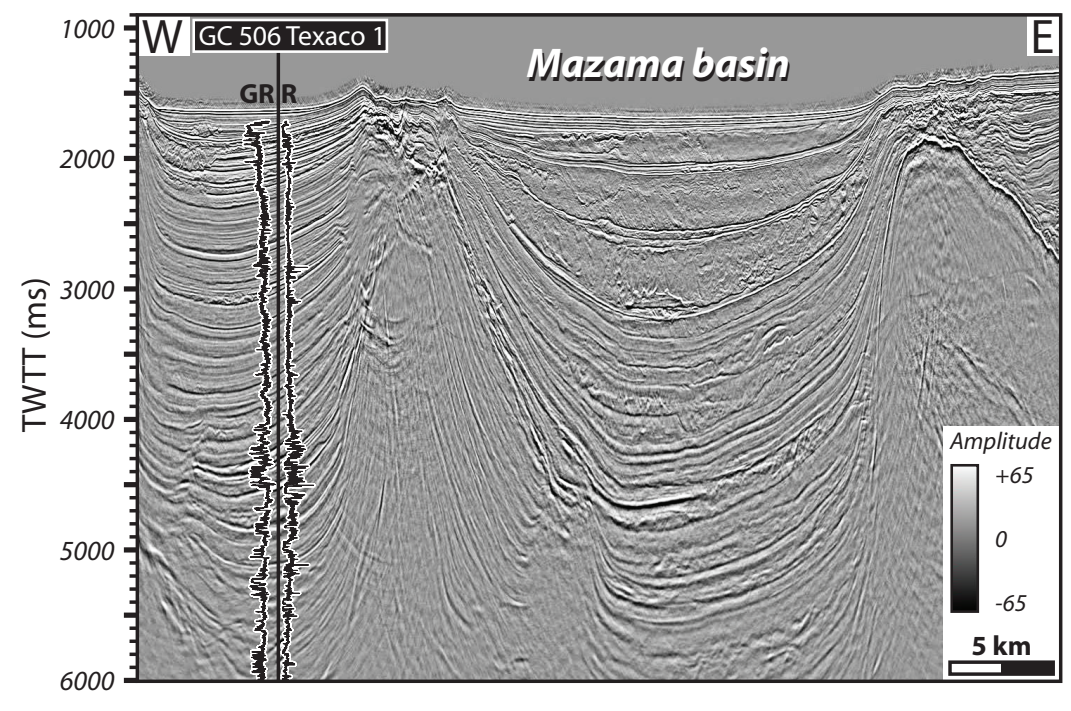

B

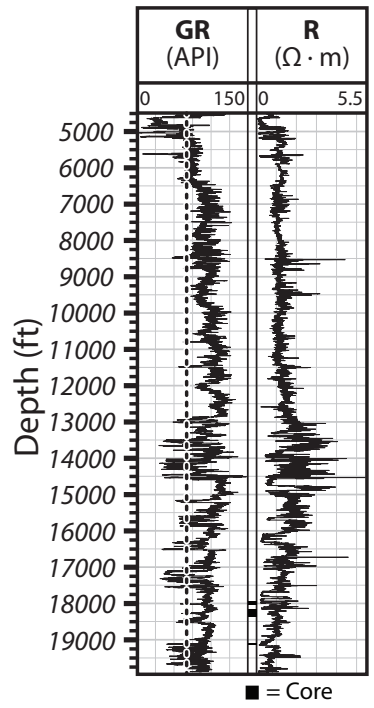

Figure 3 

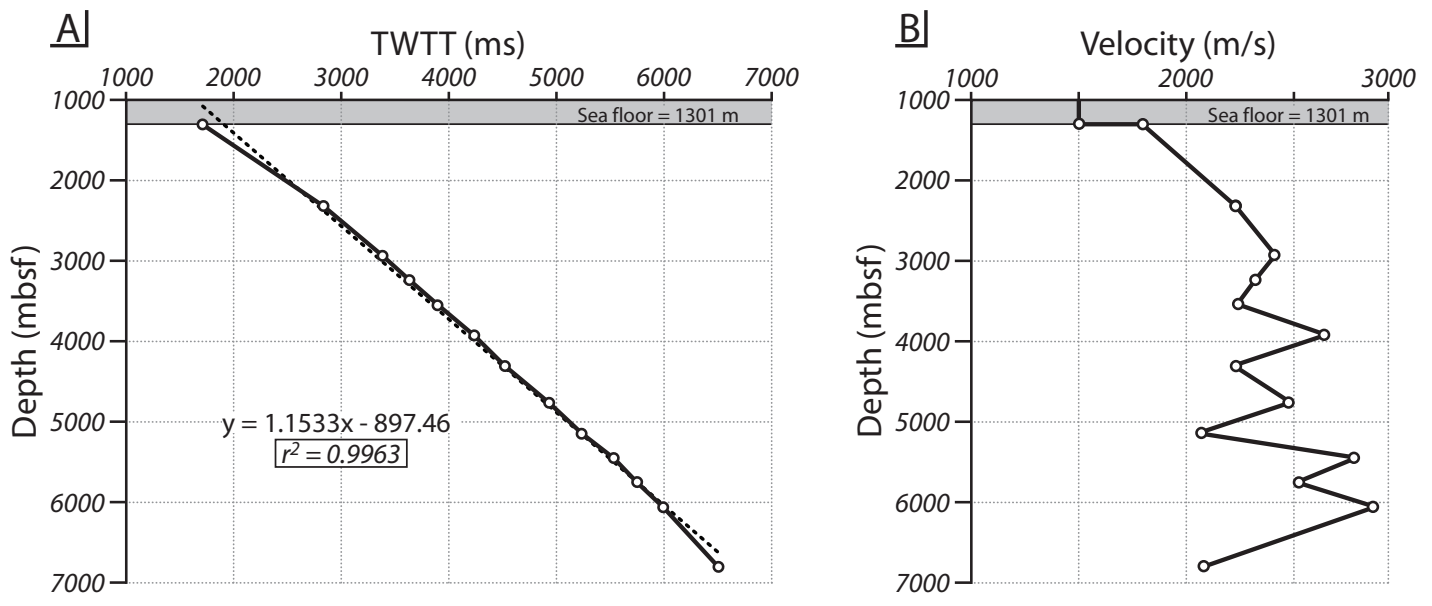

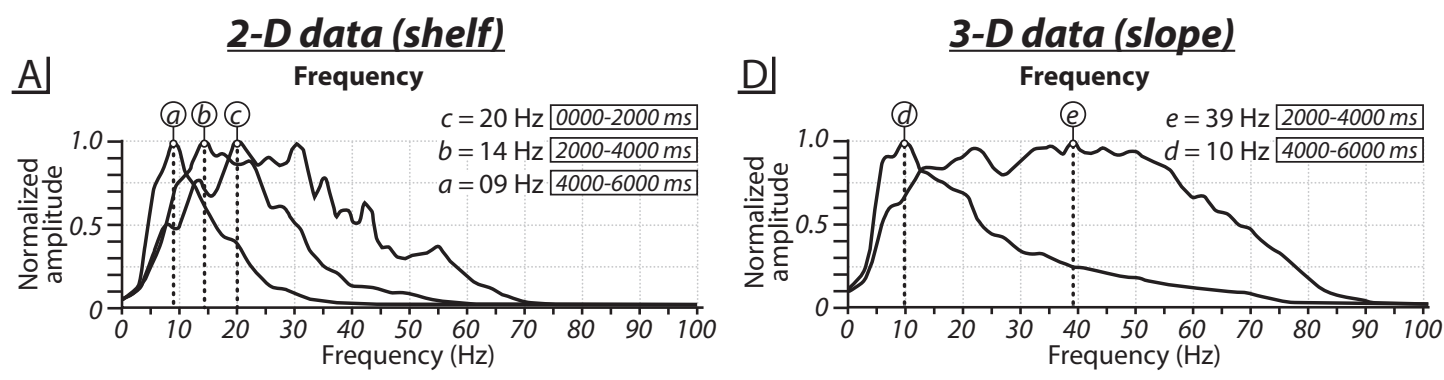

B

Phase

E

Phase
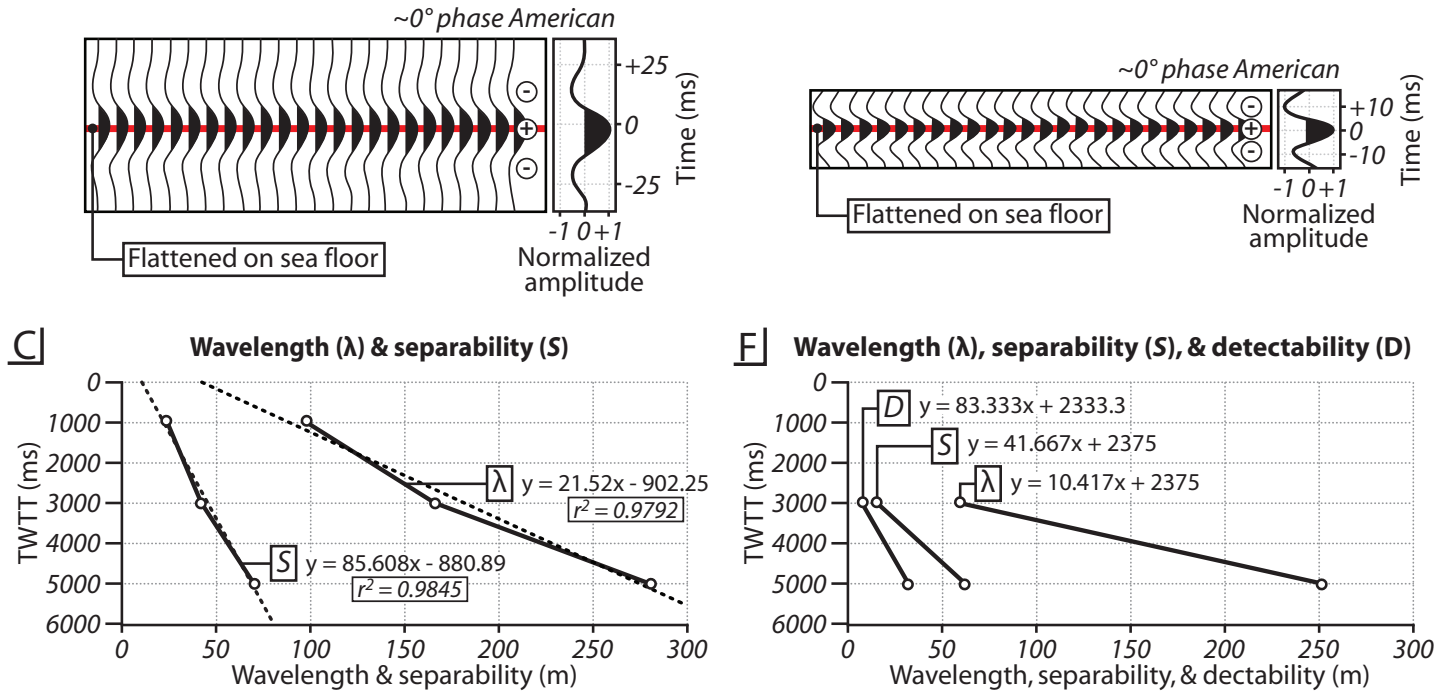

F] Wavelength $(\lambda)$, separability (S), \& detectability (D)

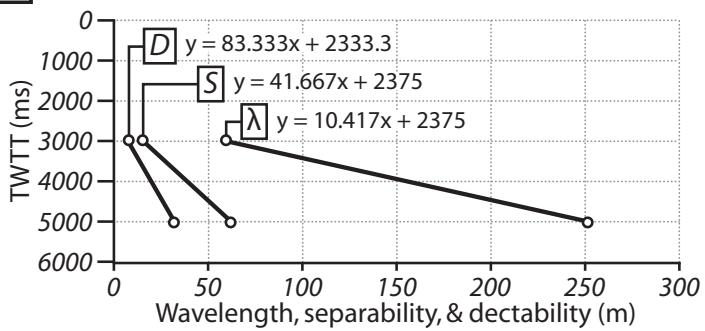




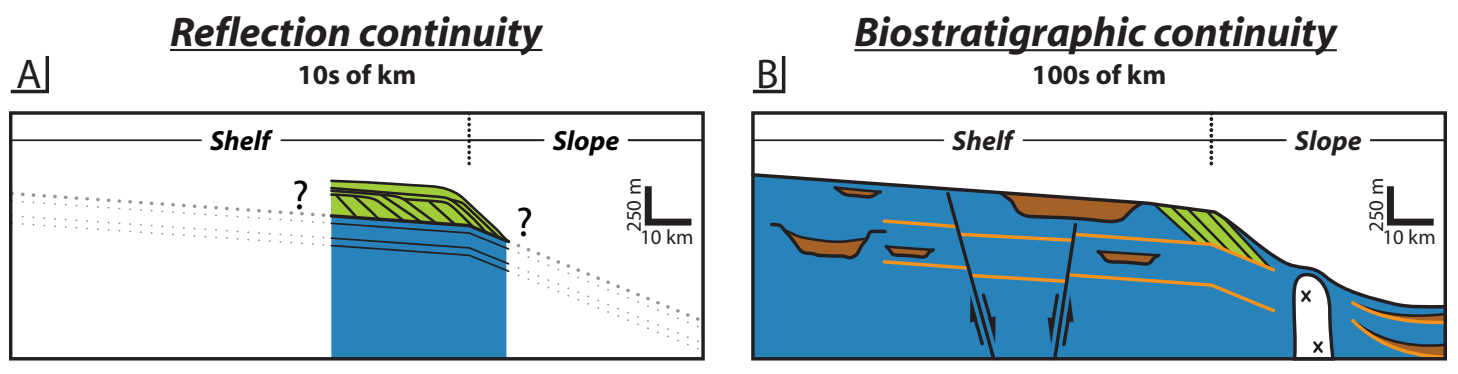

Figure 6 

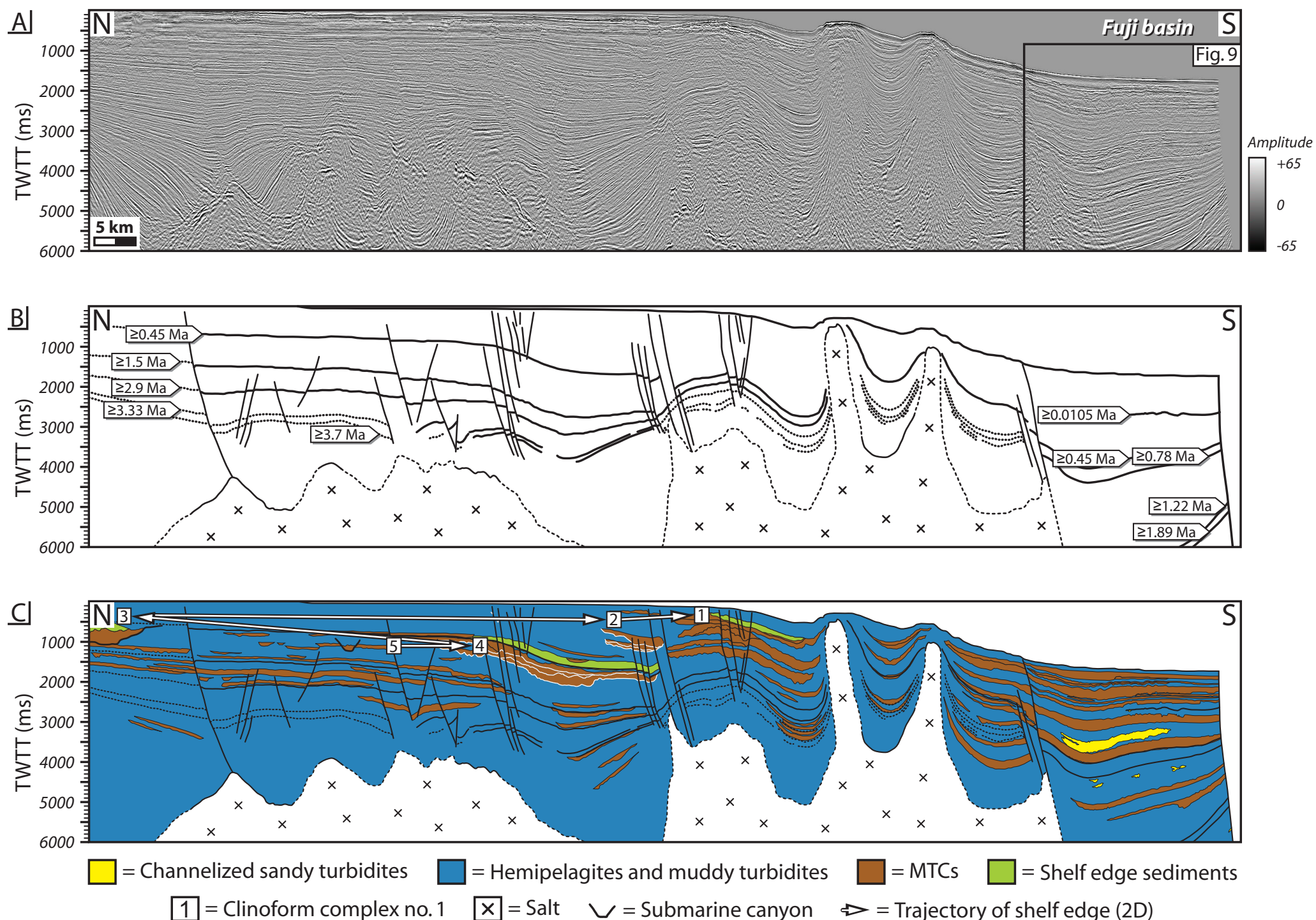

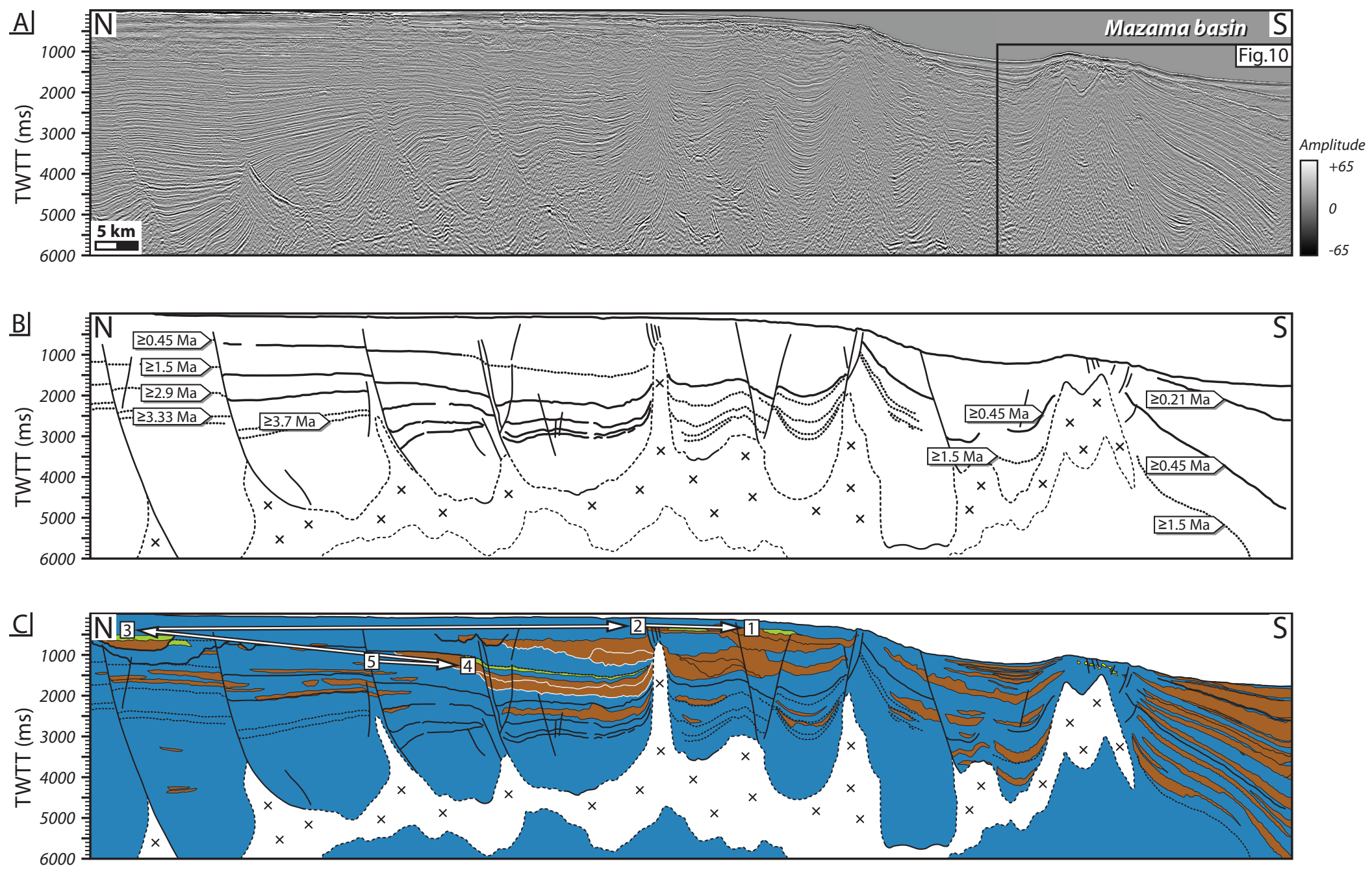

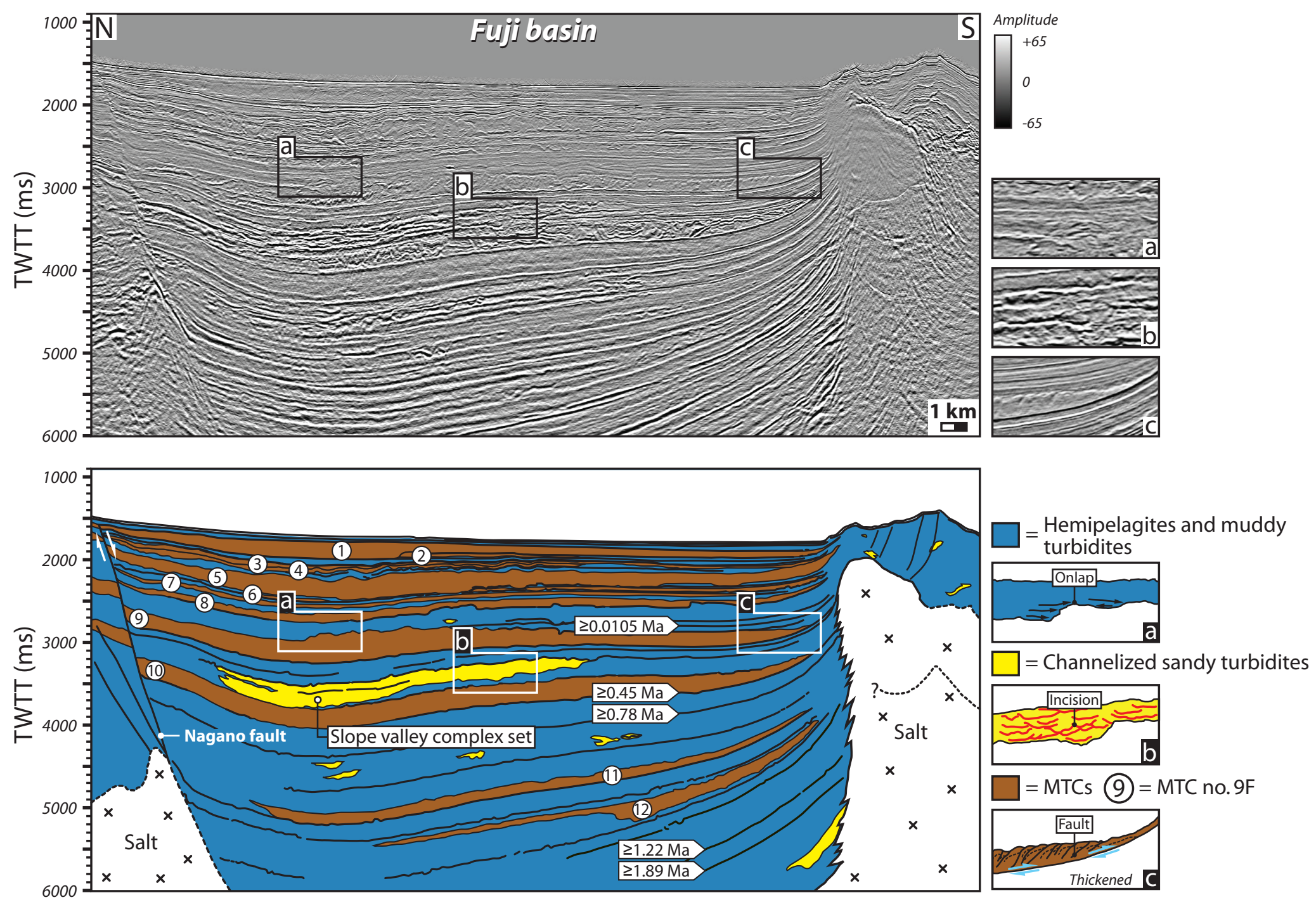

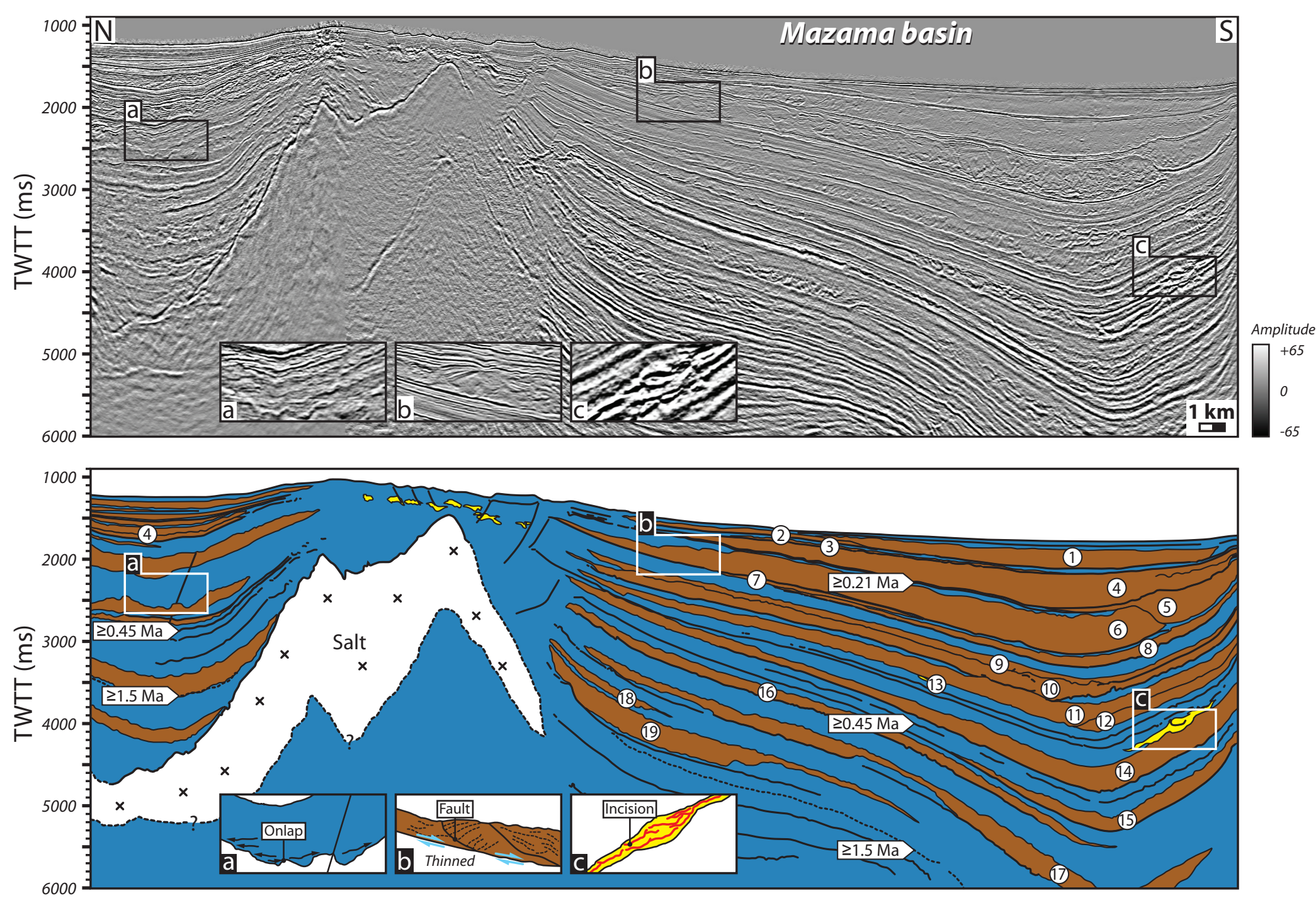

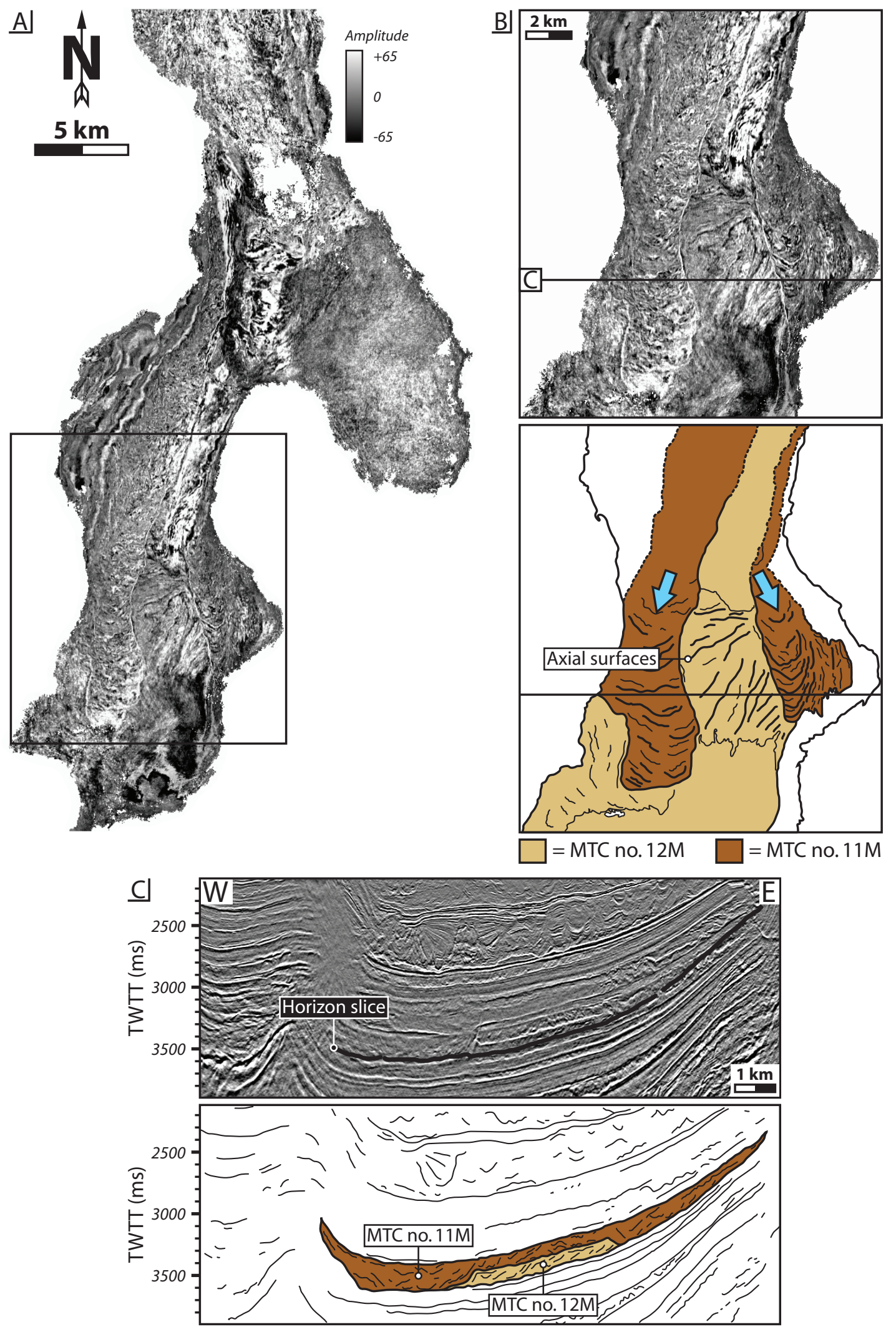

Figure 11 


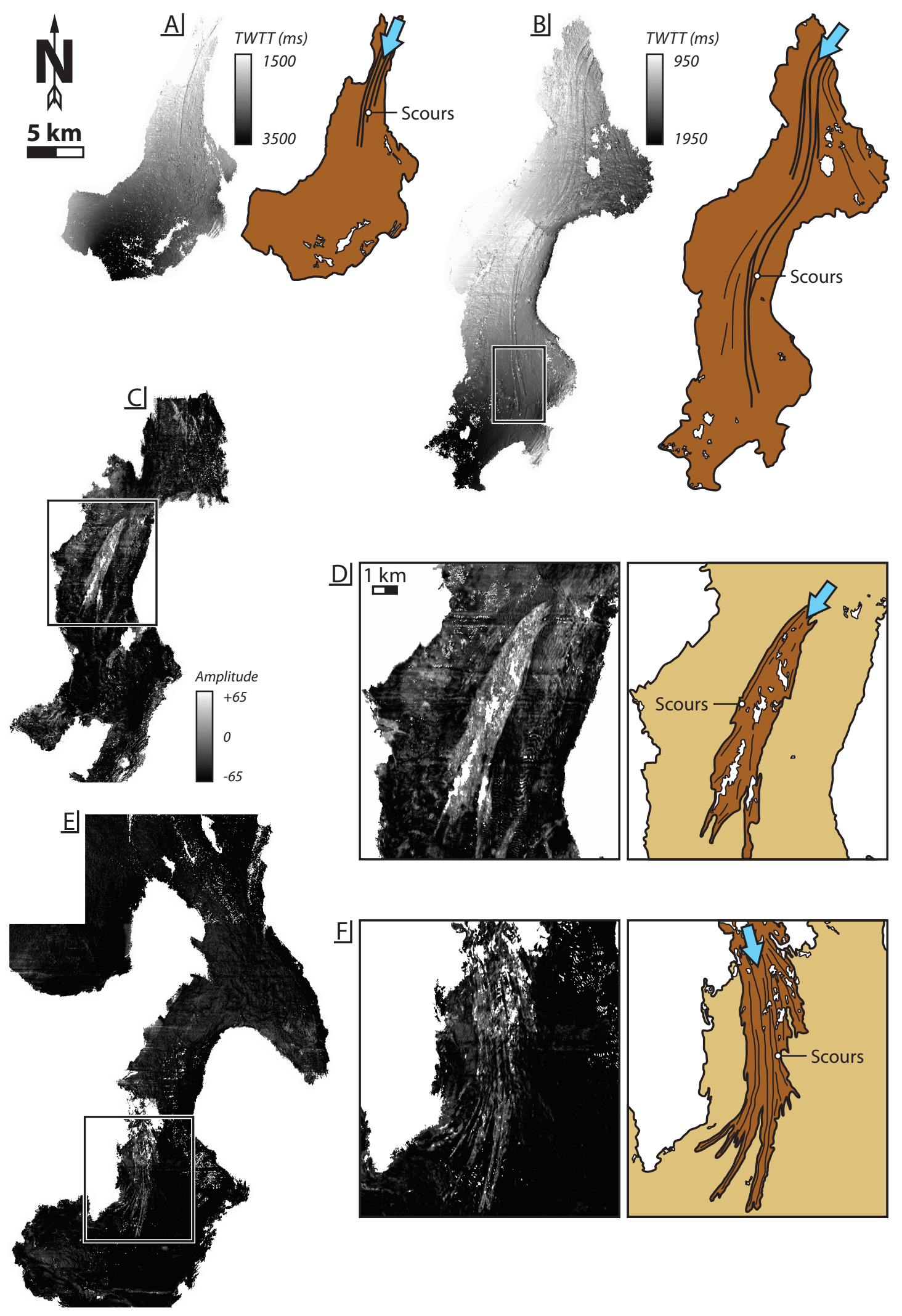

Figure 12 

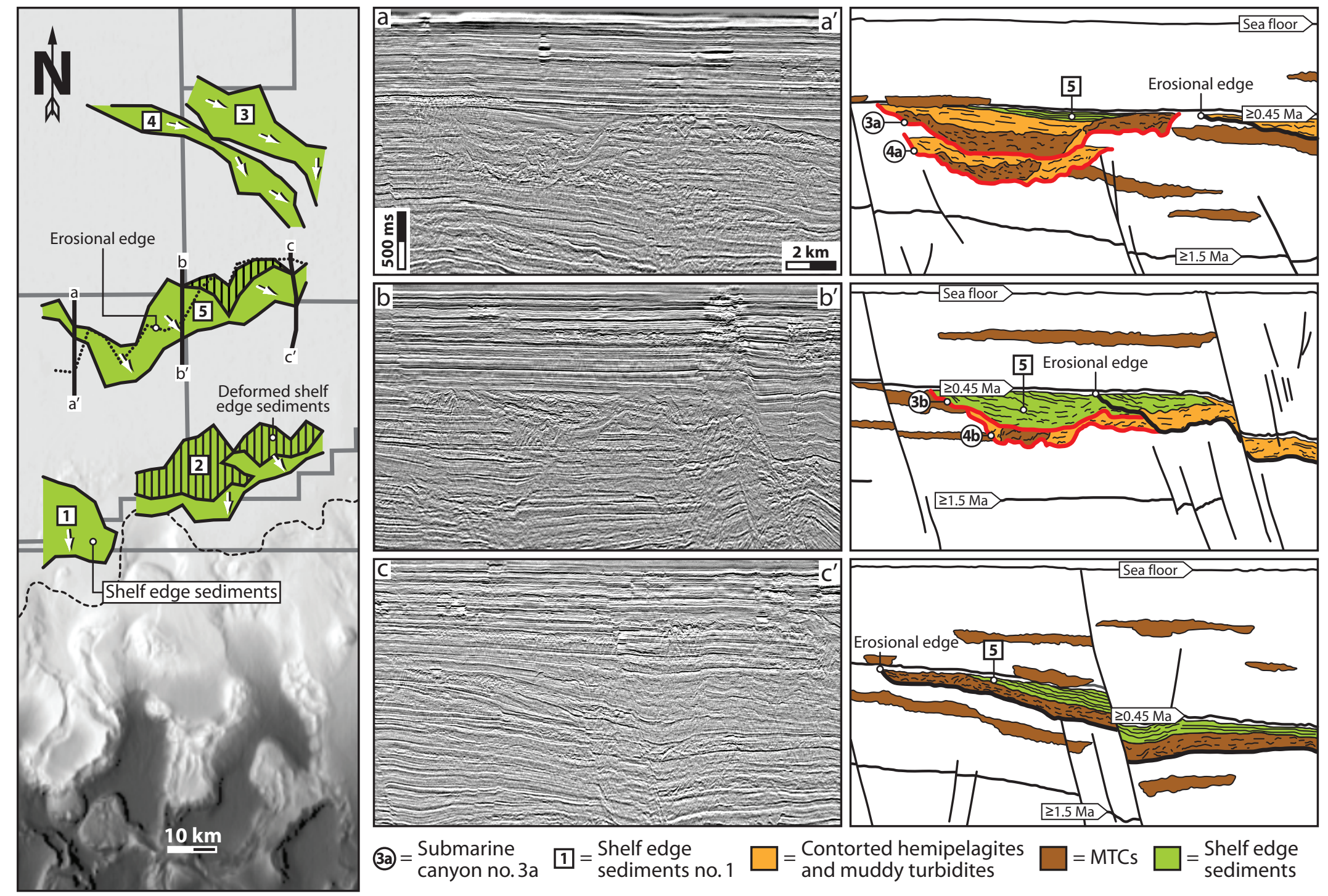

(3)= $\begin{aligned} & \text { Submarine } \\ & \text { canyon no.3a }\end{aligned} \square=\begin{aligned} & \text { Shelf edge } \\ & \text { sediments no.1 }\end{aligned} \square=\begin{aligned} & \text { Contorted hemipelagites } \\ & \text { and muddy turbidites }\end{aligned} \square=$ MTCs $\square=\begin{aligned} & \text { Shelf edge } \\ & \text { sediments }\end{aligned}$ 


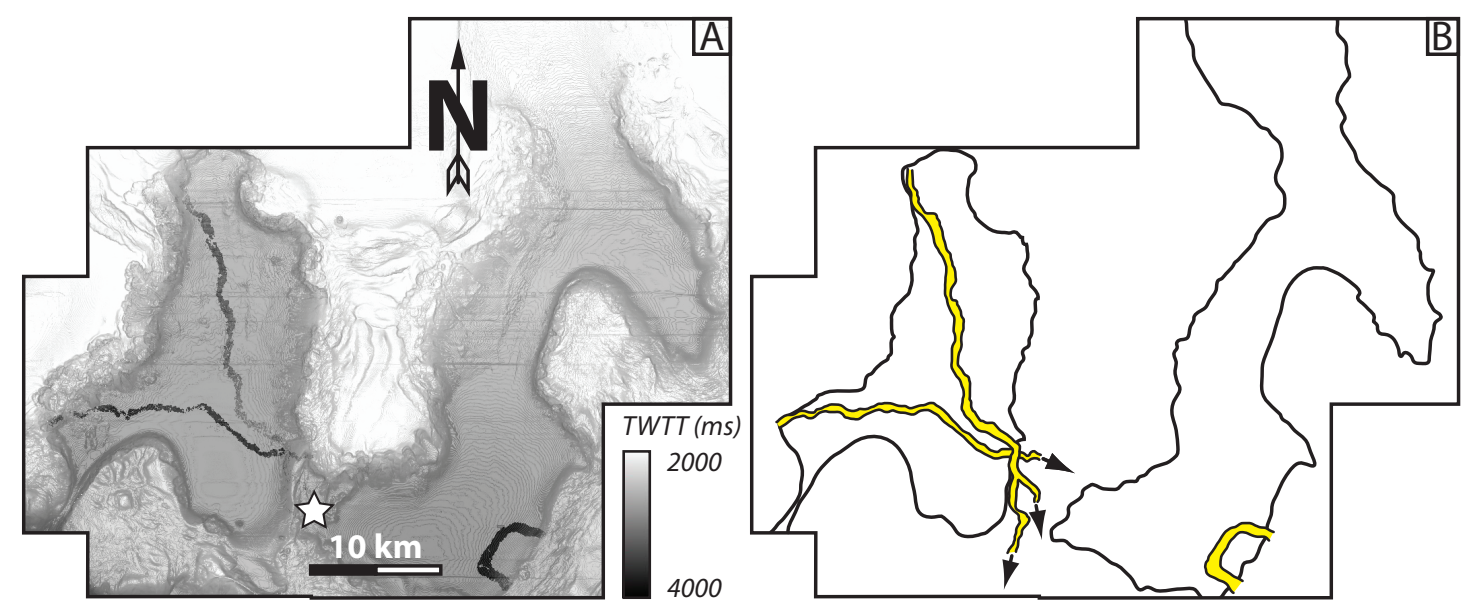

Figure 14 

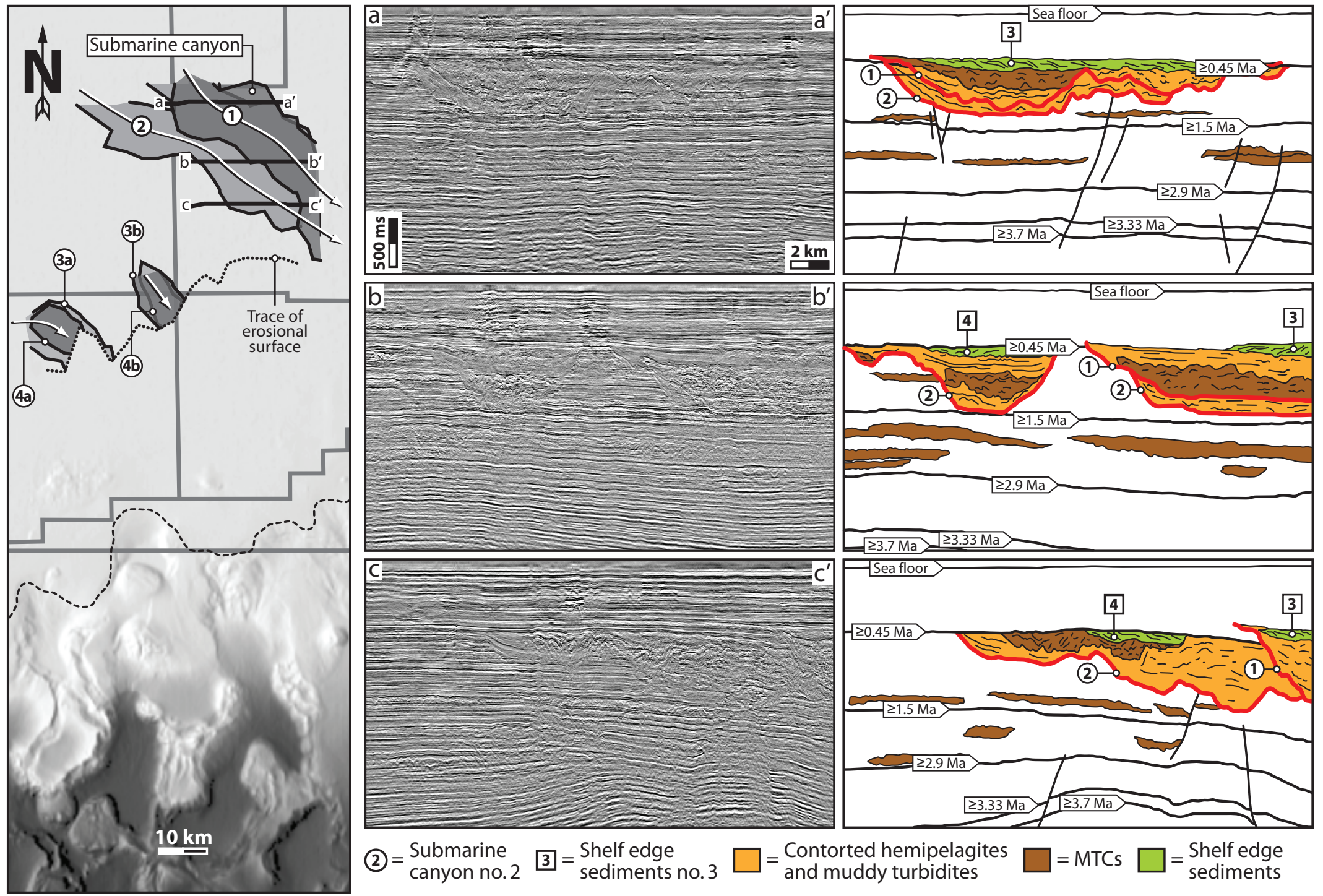

(2)= $\begin{aligned} & \text { Submarine } \\ & \text { canyon no.2 }\end{aligned} \quad \begin{aligned} & \text { Shelf edge } \\ & \text { sediments no.3 }\end{aligned} \square=\begin{aligned} & \text { Contorted hemipelagites } \\ & \text { and muddy turbidites }\end{aligned} \square=$ MTCs $\square=\begin{aligned} & \text { Shelf edge } \\ & \text { sediments }\end{aligned}$ 
Al Fuji basin
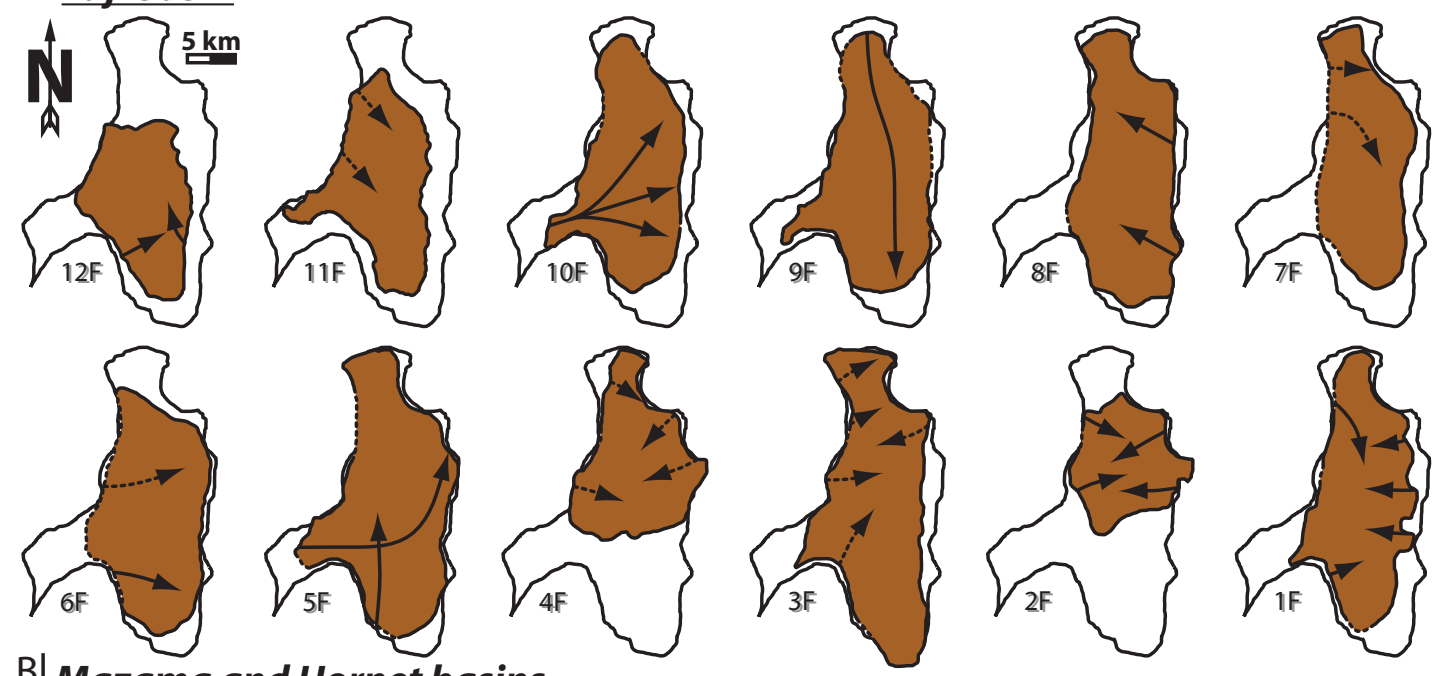

B) Mazama and Hornet basins

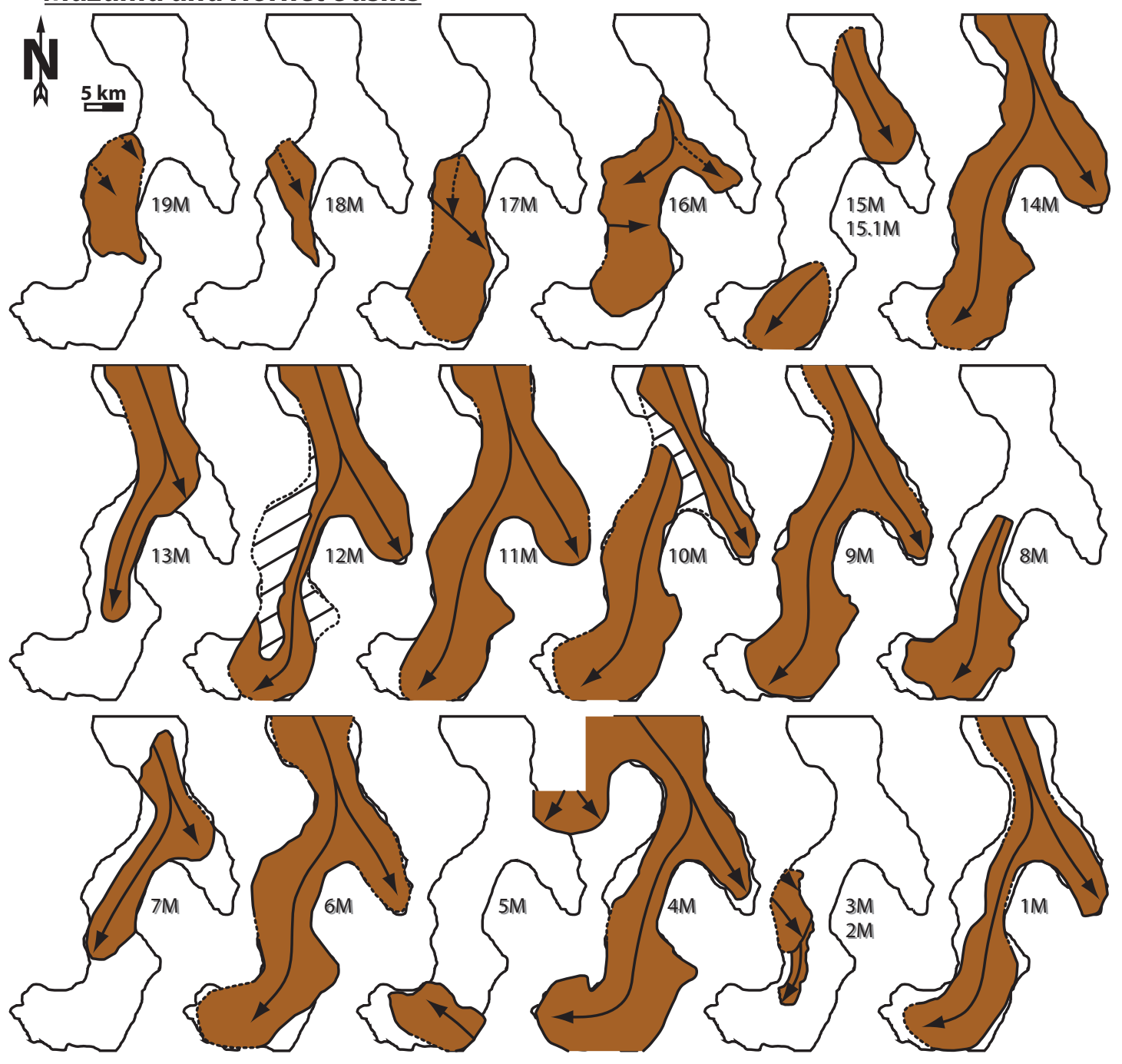

Figure 16 


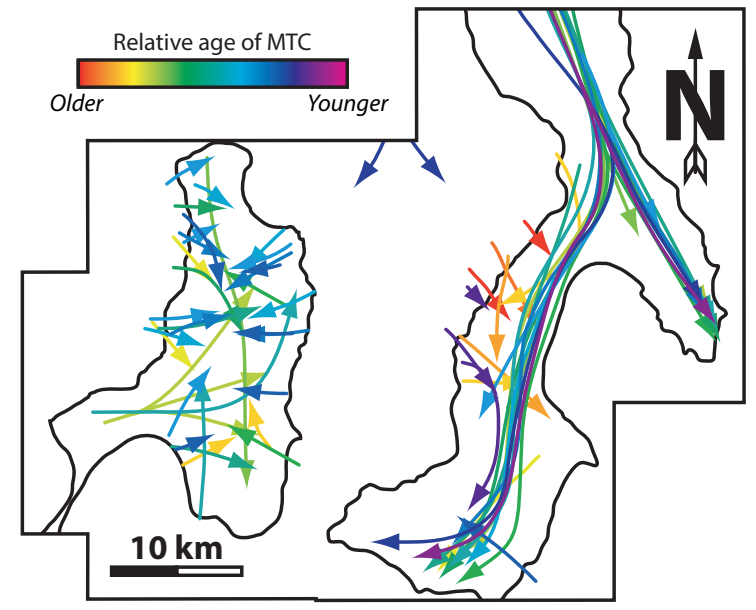

Figure 17 


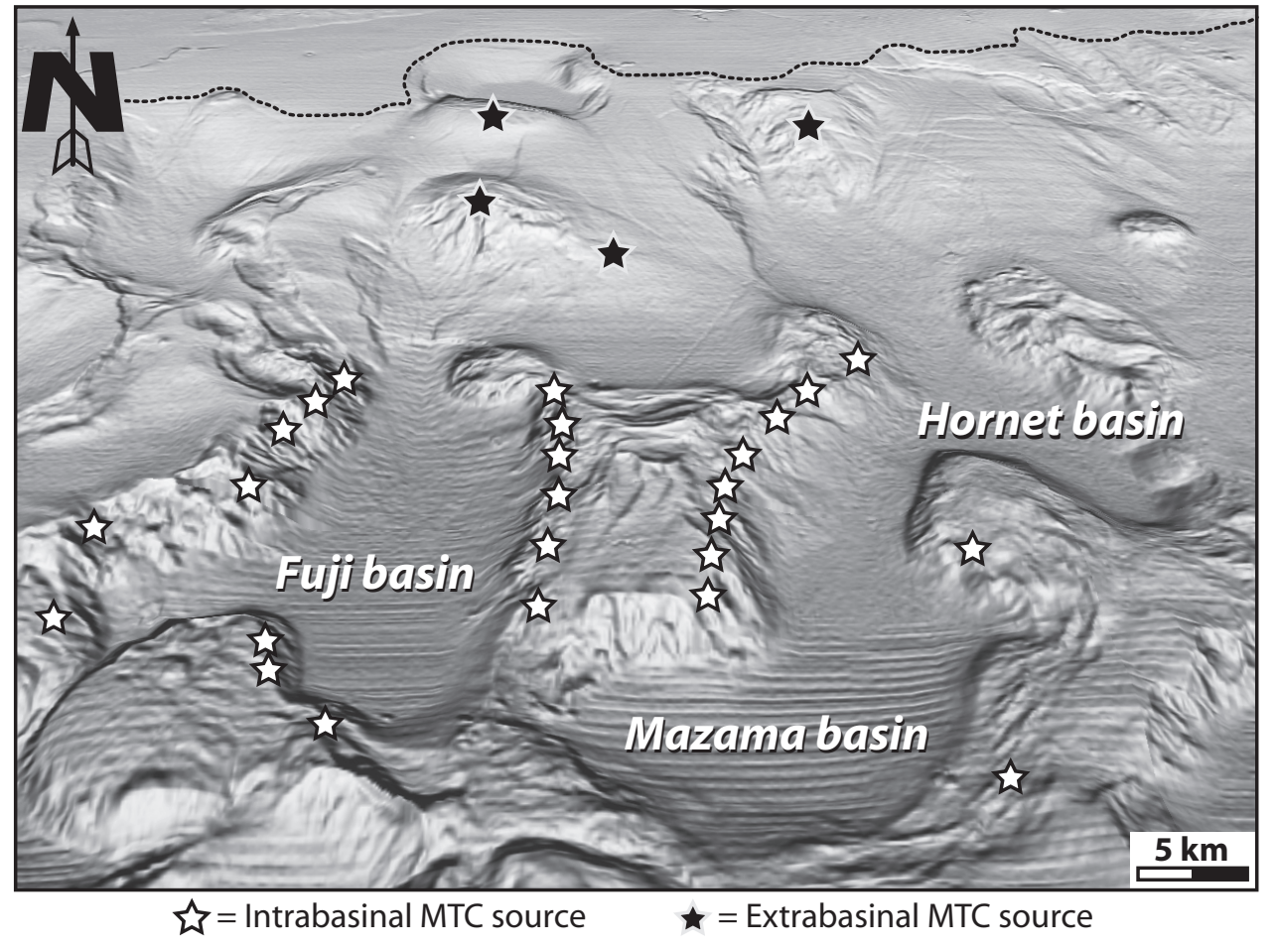

Figure 18 

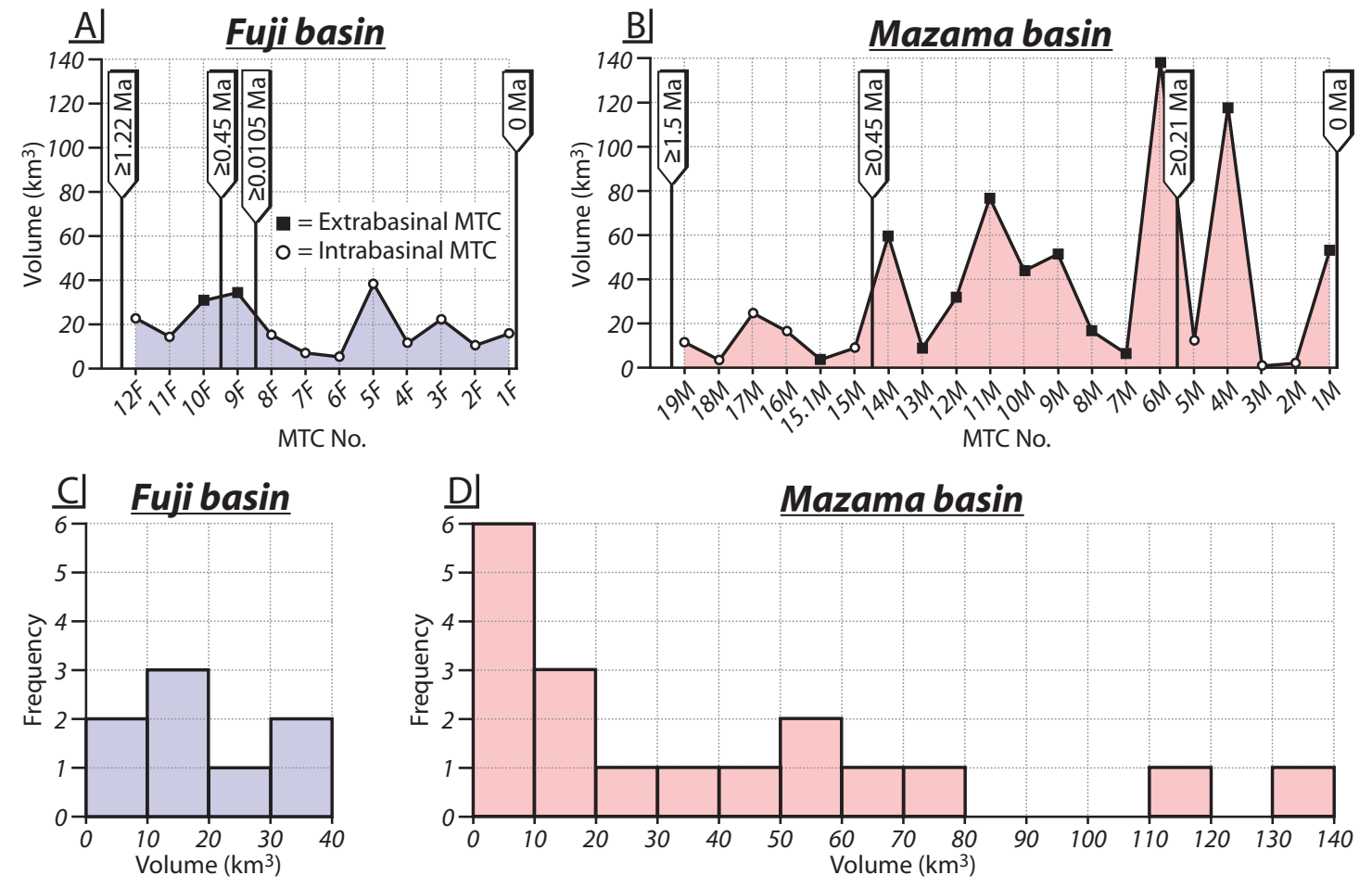

Figure 19 


\section{Fuji basin}

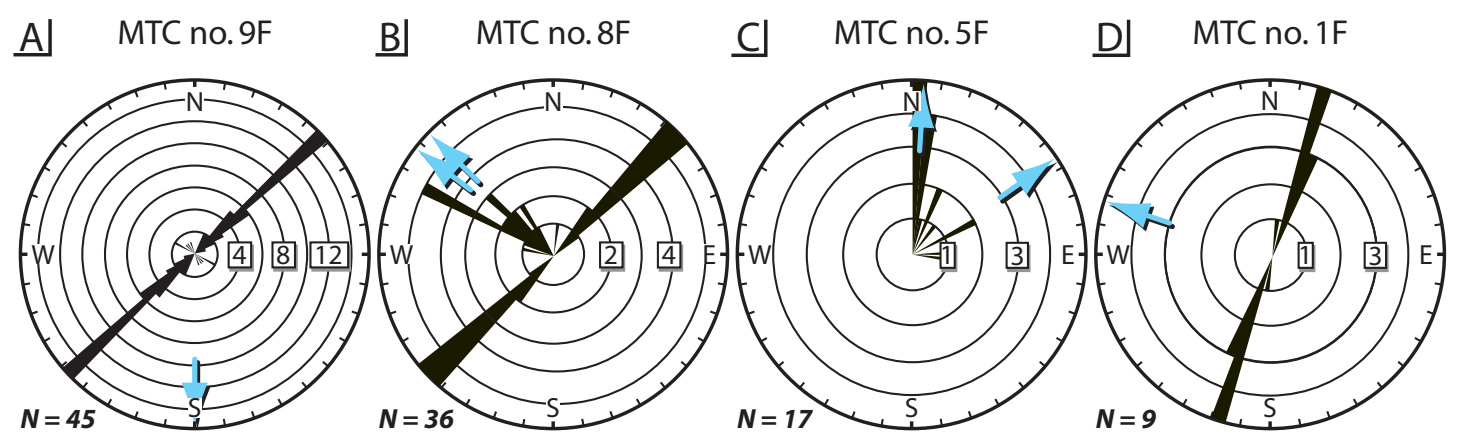

\section{Mazama basin}

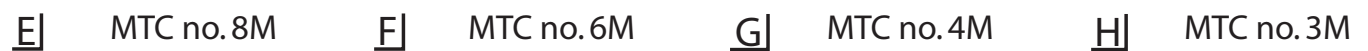

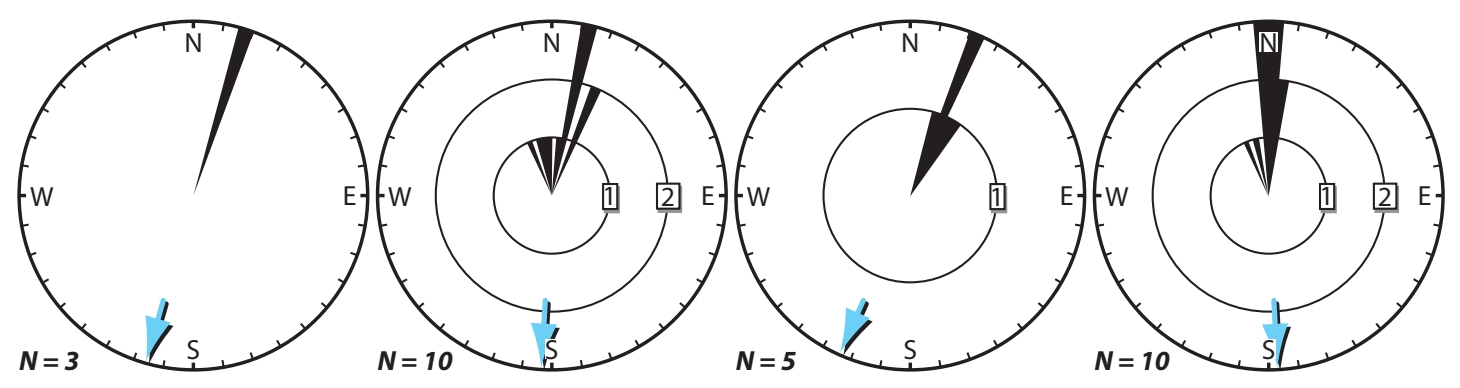

Figure 20 


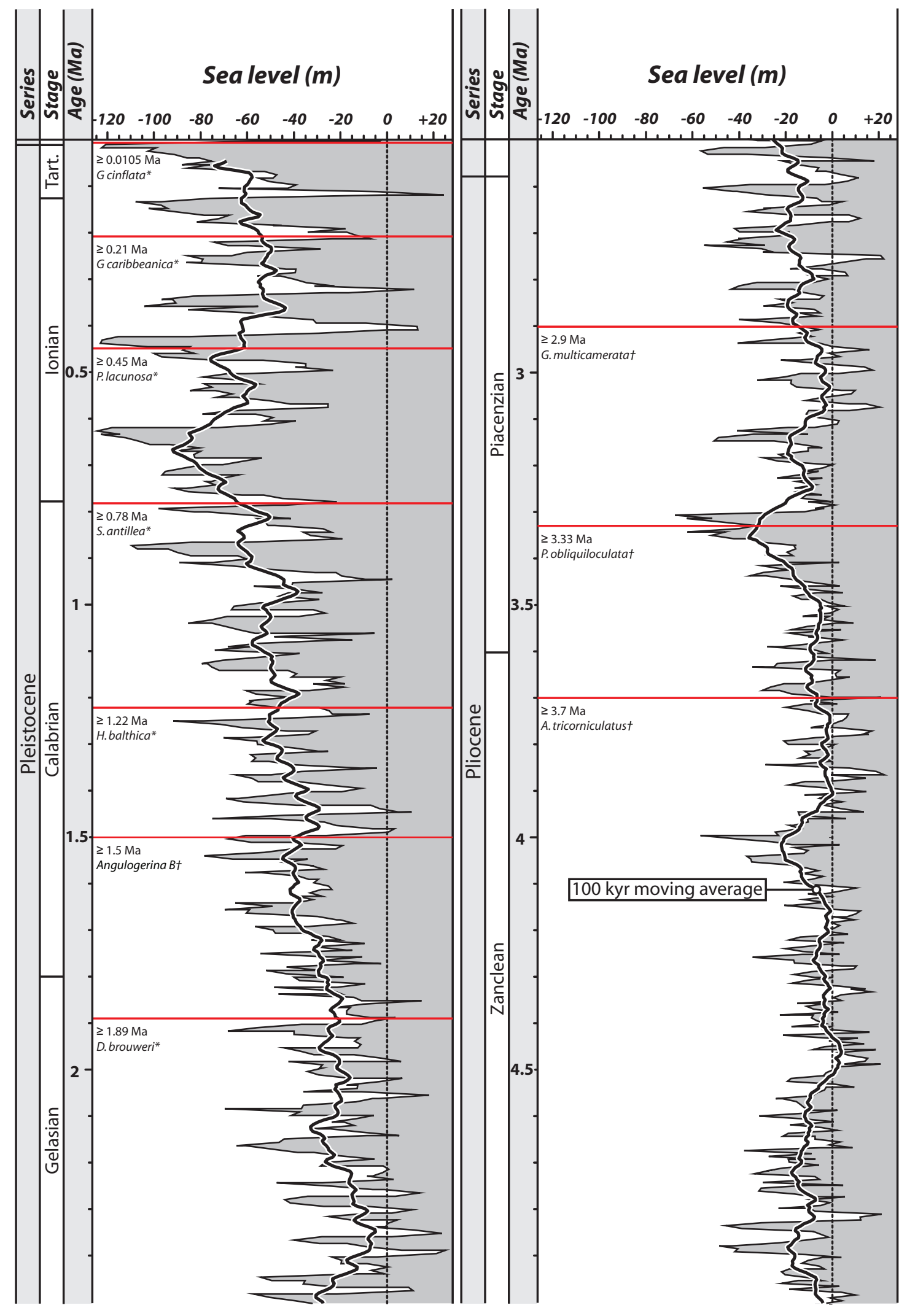

Figure 21 


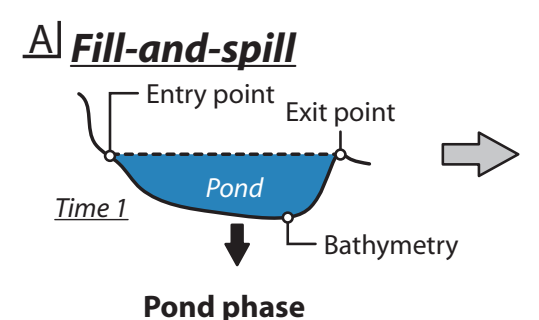

$\boldsymbol{\downarrow}$ =Subsidence $\hat{\mathrm{V}}=$ Uplift

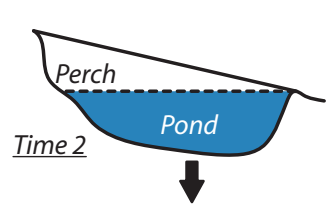

Perch phase

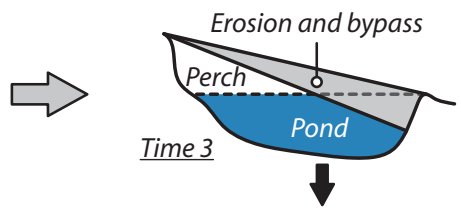

Bypass phase

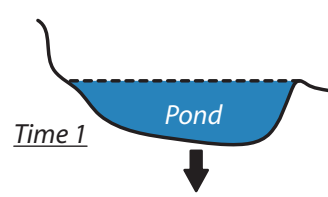

Pond phase
B Subsidence and margin faliure

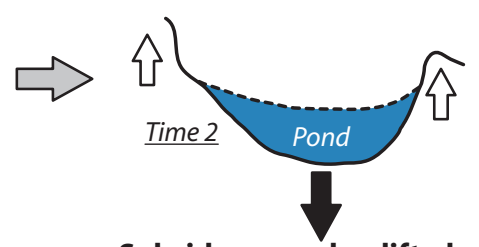

Subsidence and uplift phase

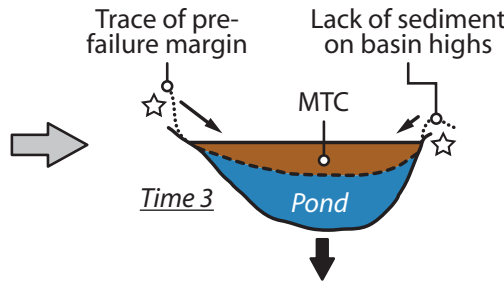

Margin failure phase 


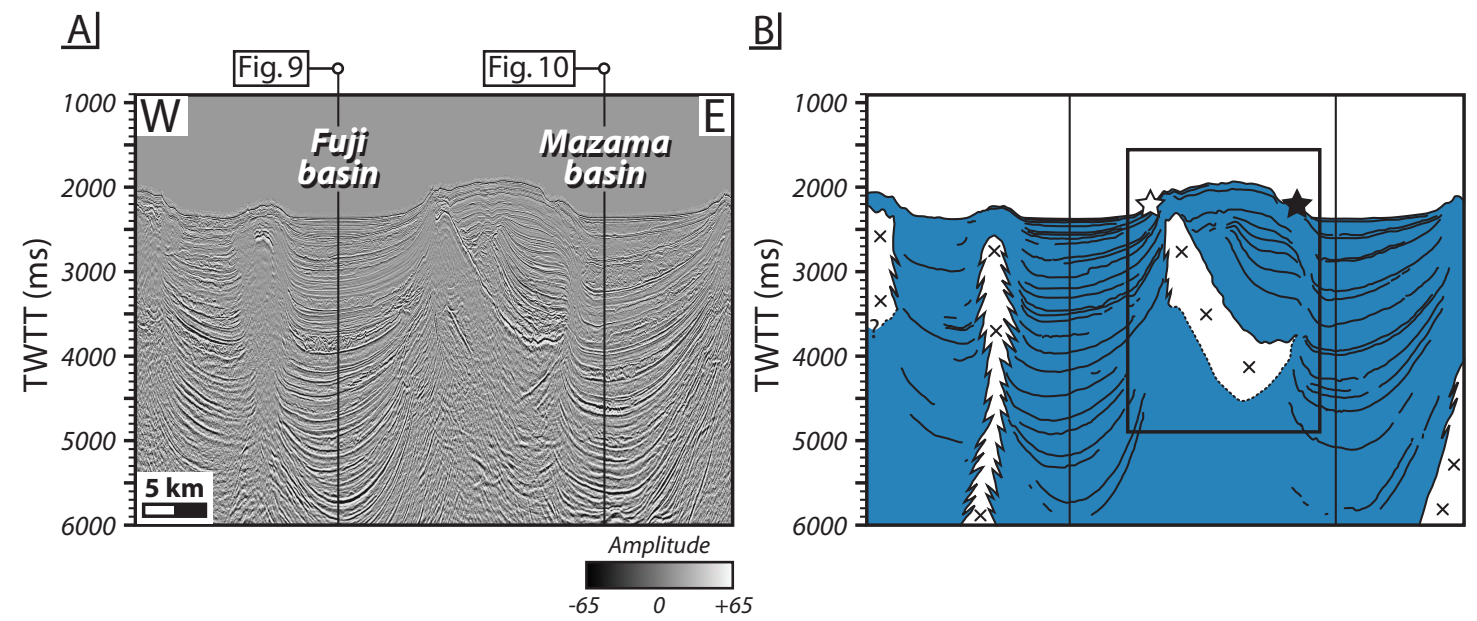

Figure 23 


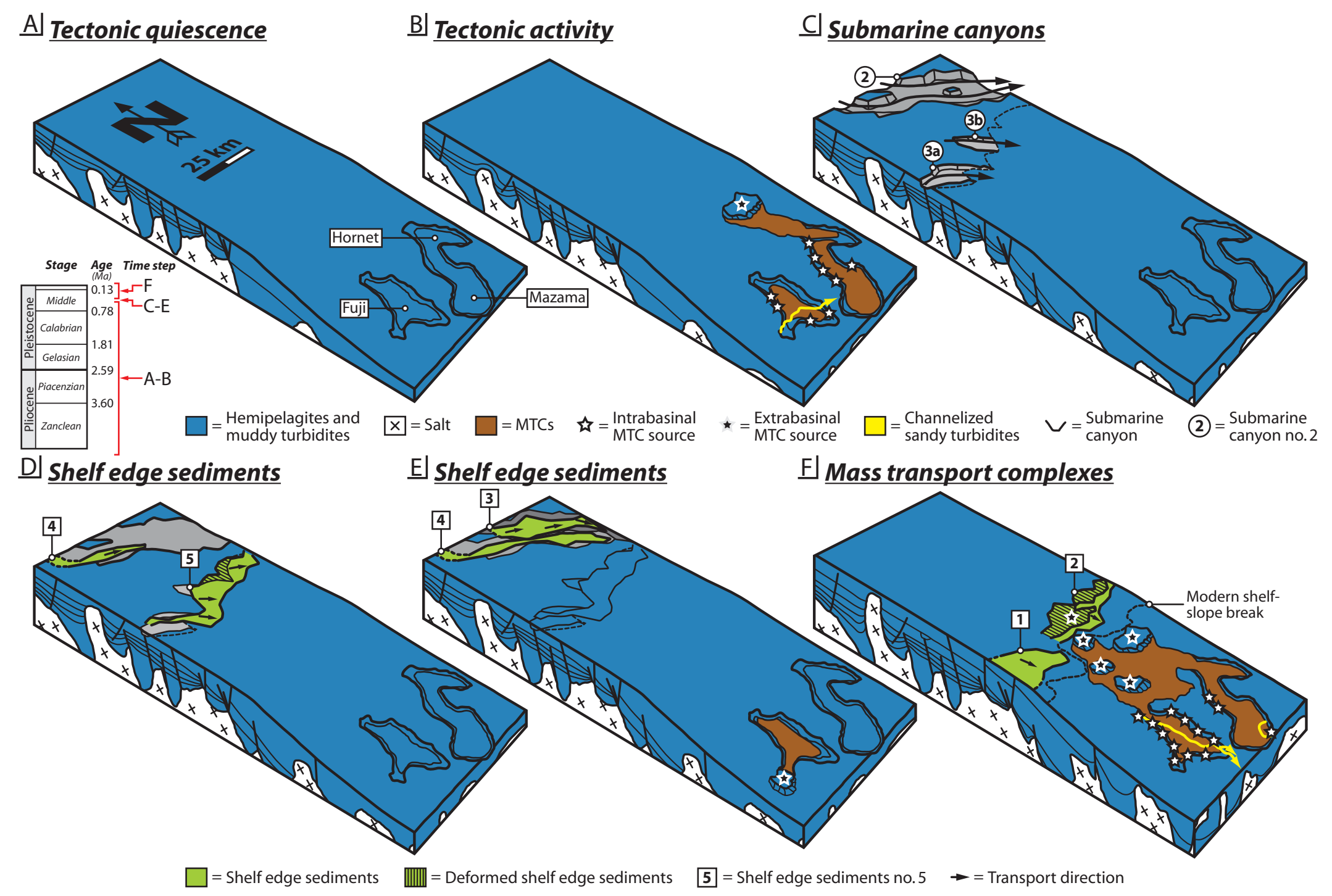


Interval (ms) Dominant frequency $(\mathrm{Hz}) \quad$ Bandwidth $(\mathrm{Hz}) \quad$ Velocity $(\mathrm{m} / \mathrm{s}) \quad$ Wavelength $(\mathrm{m}) \quad$ Separability $(\mathrm{m}) \quad$ Detectability $(\mathrm{m})$

2D data - shelf

$0000-2000$

2000-4000

4000-6000

20

14

09

2000-4000

4000-6000

$\begin{array}{ll}10-44 & 1950 \\ 08-31 & 2330 \\ 04-16 & 2518 \\ & \\ 06-68 & 2330 \\ 04-23 & 2518\end{array}$

098
166
280

060
252

024

042

070

06-68

2518

015

252 


$\begin{array}{ccrr}\begin{array}{l}\text { Maximum } \\ \text { thickness (m) }\end{array} & \begin{array}{l}\text { Maximum } \\ \text { progradation (km) }\end{array} & \begin{array}{l}\text { Progradation } \\ \text { direction }\end{array} & \begin{array}{l}\text { Underlying } \\ \text { canyon(s) }\end{array} \\ 358 & 14.5 & \mathrm{SE} & \text { No.3a and 3b } \\ 293 & 50.5 & \mathrm{SE} & \text { No. } 2 \\ 151 & 31 & \mathrm{~S}, \mathrm{SE} & \text { No.1 } \\ 310 & 19.5 & \mathrm{~S}, \mathrm{SE} & \\ 163 & 18 & \mathrm{~S} & \\ & & & \end{array}$




\begin{tabular}{lccr}
$\begin{array}{l}\text { Maximum } \\
\text { relief }(\mathbf{m})\end{array}$ & $\begin{array}{l}\text { Maximum } \\
\text { width }(\mathbf{k m})\end{array}$ & Transport direction & \multicolumn{2}{c}{ Canyon fill } \\
& & & $2,3,4$ \\
$244^{*}$ & $6.5 t$ & SE & $2,3,4$ \\
271 & $7.5 t$ & SE & 1 \\
294 & 8.5 & SE & \\
$353^{*}$ & 11.5 & SE & $2,3,4$ locally capped by 1 \\
686 & 20 & SE & $2,3,4$ locally capped by 1 \\
735 & 14 & SE & $2,3,4$ locally capped by 1
\end{tabular}

Table 3 


\section{Maximum area $\left(\mathrm{km}^{2}\right)$}

Fuji basin MTCs

$\begin{array}{lr}\text { No. 12F } & 338 \\ \text { No.11F } & 169 \\ \text { No. 10F } & 309 \\ \text { No. } 9 F & 319 \\ \text { No. 8F } & 137 \\ \text { No. 7F } & 75 \\ \text { No. 6F } & 53 \\ \text { No. 5F } & 308 \\ \text { No. 4F } & 147 \\ \text { No. 3F } & 195 \\ \text { No. 2F } & 186 \\ \text { No. 1F } & 163\end{array}$

Mazama basin MTCs

No. 19M

No. 18M

No. 17M

No. $16 \mathrm{M}$

No. 15M

No. 15.1M

No. 14M

No. 13M

No. $12 M$

No. $11 \mathrm{M}$

No. $10 \mathrm{M}$

No.9M

No. 8M

No. 7M

No.6M

No. 5M

No. 4M

No. 3M

No. 2M

No. $1 \mathrm{M}$

137
160
201
220
219
178
204
250
147
240
106
196

Volume $\left(\mathrm{km}^{3}\right)$

23
14
31
35
15
7
5
39
11
23
10
16

99

55
174

174

223
97

419

194

311

460

384

393

166

160

450

69

537

35

38
323
Features used to interpret

sediment transport direction(s)

Propagation Intra- or direction(s) extrabasinal component MTCs

Minimum number of

$\begin{array}{rrr}\mathrm{NE}, \mathrm{NW} & \text { Intra } & 2 \\ \mathrm{SE} & \text { Intra } & 2 \\ \mathrm{E}, \mathrm{NE}, \mathrm{SE} & \text { Extra } & 1 \\ \mathrm{~S} & \text { Extra } & 1 \\ \mathrm{NW} & \text { Intra } & 2 \\ \mathrm{E}, \mathrm{SE} & \text { Intra } & 2 \\ \mathrm{NE}, \mathrm{SE} & \text { Intra } & 2 \\ \mathrm{~N}, \mathrm{NE} & \text { Intra } & 2 \\ \mathrm{SE}, \mathrm{SW} & \text { Intra } & 4 \\ \mathrm{NE}, \mathrm{SW} & \text { Intra } & 5 \\ \mathrm{NE}, \mathrm{SE}, \mathrm{SW}, \mathrm{W} & \text { Intra } & 4 \\ \mathrm{NE}, \mathrm{SE}, \mathrm{W} & \text { Intra } & 5\end{array}$

$\begin{array}{rcc}\text { SE } & \text { Intra } & 2 \\ \mathrm{SE} & \text { Intra } & 1 \\ \mathrm{~S}, \mathrm{SE} & \text { Intra } & 2 \\ \mathrm{E}, \mathrm{SE}, \mathrm{SW} & \text { Intra } & 2 \\ \mathrm{SE} & \text { Extra } & 1 \\ \mathrm{SW} & \text { Intra } & 1 \\ \mathrm{SE}, \mathrm{SW} & \text { Extra } & 1 \\ \mathrm{SE}, \mathrm{SW} & \text { Extra } & 1 \\ \mathrm{SE}, \mathrm{SW} & \text { Extra } & 1 \\ \mathrm{SE}, \mathrm{SW} & \text { Extra } & 1 \\ \mathrm{SE}, \mathrm{SW} & \text { Extra } & 1 \\ \mathrm{SE}, \mathrm{SW} & \text { Extra } & 1 \\ \mathrm{SW} & \text { Extra } & 1 \\ \mathrm{SE}, \mathrm{SW} & \text { Extra } & 1 \\ \mathrm{SE}, \mathrm{SW} & \text { Extra } & 1 \\ \mathrm{NW} & \text { Intra } & 1 \\ \mathrm{~S}, \mathrm{SE}, \mathrm{SW} & \text { Extra } & 2 \\ \mathrm{~S} & \text { Intra } & 1 \\ \mathrm{SE} & \text { Intra } & 2 \\ \mathrm{SE}, \mathrm{SW} & \text { Extra } & 2\end{array}$

$1,4,5$
5
1,5
1,5
$1,4,5$
1,5
$1,2,5$
4,5
1,5
1,5
$1,2,5$
$1,2,5$

4,5
4,5
1,5
1,5
4,5
1,5
$1,4,5$
$1,4,5$
$1,4,5$
1,5
1,5
1,5
$1,4,5$
4,5
$1,4,5$
1,5
$1,4,5$
4,5
$1,4,5$
1,5


MTC no.8M MTC no.6M MTC no.4M MTC no.3M

$\begin{array}{llll}015 & 006 & 016 & 001 \\ 015 & 011 & 023 & 001 \\ 017 & 011 & 024 & 004 \\ & 012 & 027 & 006 \\ & 021 & 031 & 009 \\ & 022 & & 337 \\ & 335 & & 346 \\ & 345 & & 355 \\ & 354 & & 356 \\ & 357 & & 356\end{array}$

Table 5 